Article

\title{
Control of the Air Supply Subsystem in a PEMFC with Balance of Plant Simulation
}

\author{
Alan Cruz Rojas ${ }^{1}$, Guadalupe Lopez Lopez ${ }^{1, *}$, J. F. Gomez-Aguilar ${ }^{2}$, Victor M. Alvarado ${ }^{1}$ \\ and Cinda Luz Sandoval Torres ${ }^{1}$ \\ 1 TecNM, CENIDET, Interior Internado Palmira S/N, Col. Palmira, 62490 Cuernavaca, Morelos, Mexico; \\ alan11e@cenidet.edu.mx (A.C.R.); alvarado@cenidet.edu.mx (V.M.A.); cindaluz@cenidet.edu.mx (C.L.S.T.) \\ 2 CONACYT-TecNM, CENIDET, Interior Internado Palmira S/N, Col. Palmira, 62490 Cuernavaca, Morelos, \\ Mexico; jgomez@cenidet.edu.mx \\ * Correspondence: guadalupe@cenidet.edu.mx; Tel.: +52-777-151-3939
}

Academic Editor: Tomonobu Senjyu

Received: 14 November 2016; Accepted: 3 January 2017; Published: 7 January 2017

\begin{abstract}
This paper deals with the design of a control scheme for improving the air supply subsystem of a Proton Exchange Membrane Fuel Cell (PEMFC) with maximum power of $65 \mathrm{~kW}$. The control scheme is evaluated in a plant simulator which incorporates the balance of plant (BOP) components and is built in the aspenONE ${ }^{\circledR}$ platform. The aspenONE ${ }^{\circledR}$ libraries and tools allows introducing the compressor map and sizing the heat exchangers used to conduct the reactants temperature to the operating value. The PEMFC model and an adaptive controller were programmed to create customized libraries used in the simulator. The structure of the plant control is as follows: the stoichiometric oxygen excess ratio is regulated by manipulating the compressor power, the equilibrium of the anode-cathode pressures is achieved by tracking the anode pressure with hydrogen flow manipulation; the oxygen and hydrogen temperatures are regulated in the heat exchangers, and the gas humidity control is obtained with a simplified model of the humidifier. The control scheme performance is evaluated for load changes, perturbations and parametric variations, introducing a growing current profile covering a large span of power, and a current profile derived from a standard driving speed cycle. The impact of the control scheme is advantageous, since the control objectives are accomplished and the PEMFC tolerates reasonably membrane damage that can produce active surface reduction. The simulation analysis aids to identify the safe Voltage-Current region, where the compressor works with mechanical stability.
\end{abstract}

Keywords: PEM fuel cell; aspenONE; oxygen excess ratio; MRAC

\section{Introduction}

The automotive industry has strongly promoted the development of electric vehicles. Recent trends in this industry allow the commerce of vehicles powered by Proton Exchange Membrane Fuel Cells (PEMFC). The first commercial models, Hyundai ix35 FCEV or Tucson Fuel Cell (100 kW) started production at Ulsan Korea in 2013 and then distributed in Europe and other countries in 2015 [1]. The Toyota Mirai model $(114 \mathrm{~kW})$ was launched in Japan in December 2014 [2]. Honda has been developing fuel cell cars for decades, the Honda FCX Clarity $(100 \mathrm{~kW})$ model was produced between 2008 and 2014 but a new series is offered for lease from spring 2016 [3]. Mercedes-Benz B-Class F-Cell $(100 \mathrm{~kW})$ is on the testing process, thus few units have been sold to reduced groups since 2010 [4]. In the United States, the sales of vehicles powered by fuel cells are restricted to areas with sufficient hydrogen fueling stations [5]. A public-private partnership in California is making one of the first efforts to promote hydrogen powered vehicles [6]. In this state, the established hydrogen stations guarantee the autonomy of the fuel cell vehicles market. 
Even when the PEMFC technology is highly attractive for portable and vehicular markets, it is not entirely mature in terms of cost, size and marketing level. Nowadays, PEMFC powered vehicle prototypes are mostly in evaluation and testing stages; at this point, a demanding task is to improve the design and the performance of the fuel cell-based power systems. The various challenges of PEMFC researches usually engage thorough analysis coming from comprehensive PEMFC system models and simulators developments. From the viewpoint of dealing with a power system, a PEMFC must operate under appropriate conditions of temperature, pressure, flow and humidity. The coupling of auxiliary equipment forms a fuel cell system and aids to attain the design operating conditions. The coordinated operation of all the components of the fuel cell system is known as the balance of plant (BOP). The dynamics of the auxiliary components have a decisive effect on the fuel cell performance, especially in systems delivering power higher than $10 \mathrm{~kW}$. In particular, electric vehicles need power from 50 to $100 \mathrm{~kW}$, depending on their size and use.

Summarizing, the auxiliary equipment deals with reactants supply and with temperature and humidity management in fuel cell systems. One of the former works on modeling, dynamic analysis, control and optimization of PEMFC systems was reported by Pukrushpan, 2004 [7], it was considered the basis for developing the simulator of the present study. The control of the reactants supply is of relevant importance for conceiving PEMFC power systems. Fang, 2015 [8], for example, modeled a hydrogen injection subsystem, consisting of gaseous fuel injectors that offer greater flexibility for controlling the anode pressure, and consequently for compensating abrupt pressure reduction when purge occurs. But a major concern in the system management is the air supply subsystem; herein the problems of oxygen excess ratio regulation, equalization of anode and cathode pressures and water management control are essentially addressed in PEMFC control studies using a variety of techniques, e.g., nonlinear model-based predictive control of gas pressures was applied to deal with different events of errors in PEMFC systems, along with several types of dynamic load changes $[9,10]$. It has been acknowledged that oxygen excess ratio control is one of the most important actions to enhance protection and performance of fuel cells; thus, well-suited control strategies with this target have been proved, three related works are the following: a sliding mode control achieved by adjusting the compressor supply voltage was assisted with a nonlinear observer predicting the oxygen excess ratio and improved with a novel tuning procedure [11]. In a second work, a feedforward fuzzy-PID control was proposed; the model used for designing the oxygen excess ratio controller included cathode and anode mass flow transients, membrane hydration dynamics, as well as the fuel cell BOP simulation [12], the controller was developed to adapt the PID parameters to achieve the regulation of the air flow rate using on-line fuzzy logic optimization loop. A third approach used adaptive control under exigent scenarios [13,14]. Similar control objectives are addressed by designing classical PI and PIDs controllers [15] or enhanced PI tuning based on genetic algorithms [16]. More recently, fault-tolerant control strategies [17] are applied. Typically, the control problem must deal with non-linear behaviors of the plant; however, control oriented linear models such as state-space models [18] and identification models [19] are also developed.

The BOP control structure also includes the regulation or monitoring of the power delivered by the fuel cell; the management of temperature to treat the problems of feeding reactants temperature regulation, as well as the fuel cell stack cooling to mitigate the heat produced by the exothermic reactions using a heat removing circuit [20-24]. A current topic is the development of hybrid systems [25-32]; therefore, the addition of peripheral elements, such as auxiliary power units or backup sources intensifies the challenge of modeling highly coupled multi-physical systems. There are also complete studies concerning the design, improvement or modeling of converters for fuel cell applications (e.g., [33-35]). Kim, 2015 [36] proposed a process for implementing new renewable energy systems, and offered an analysis of the key factors affecting system performances of fuel cell systems.

Some simulation platforms provide tools and libraries that facilitate the integration of subsystems in specialized simulation environments. Studies about PEMFC systems have presented advanced process simulators, for example, Ziogou, 2011 [37] reported the use of the gPROMS platform to 
simulate a PEMFC BOP. A well-known software for process engineering applications is the Advanced System for Process Engineering (aspenONE ${ }^{\circledR}$ v8, Aspen Technology, Inc., Burlington, MA, USA). This simulation platform has been widely applied for process design and development on various renewable energy sources areas, some examples are the works on biomass or solid waste utilization for gasification [38-41]. More related works are those of Rabbani, 2013 [42], who took advantage of the Aspen Plus ${ }^{\circledR}$ simulator to model and control a Ballard power module of $21.2 \mathrm{~kW}$, and presented a dynamic analysis for vehicular applications. Also within the Aspen Plus ${ }^{\circledR}$ platform, two simulators of fuel cell systems were built in which a steam reforming subsystem was considered for hydrogen production: Salemme, 2010 and $2013[43,44]$ calculated the operative conditions that maximize the energy efficiency of a PEMFC system; and Suther, 2010 [45] developed a simulator with a macro-level model for a Solid Oxide Fuel Cell (SOFC) stack, this model yields the output composition of the exhaust and the produced work, and calculates the heat available for the fuel reformer and the electrochemical properties of the SOFC.

In this paper, a control scheme for a PEMFC with BOP components simulation is presented. The dynamic simulation of the PEMFC BOP is executed in the aspenONE ${ }^{\circledR}$ platform for maximal power solicitations of $65 \mathrm{~kW}$. The built simulator includes a compressor for oxygen supply, two heat exchangers to regulate the temperature of the reactants at the electrodes inputs, and a humidifier to saturate with water the air entering into the fuel cell. The overall system diagram is depicted in Figure 1 and the control structure is entirely described in Section 3.

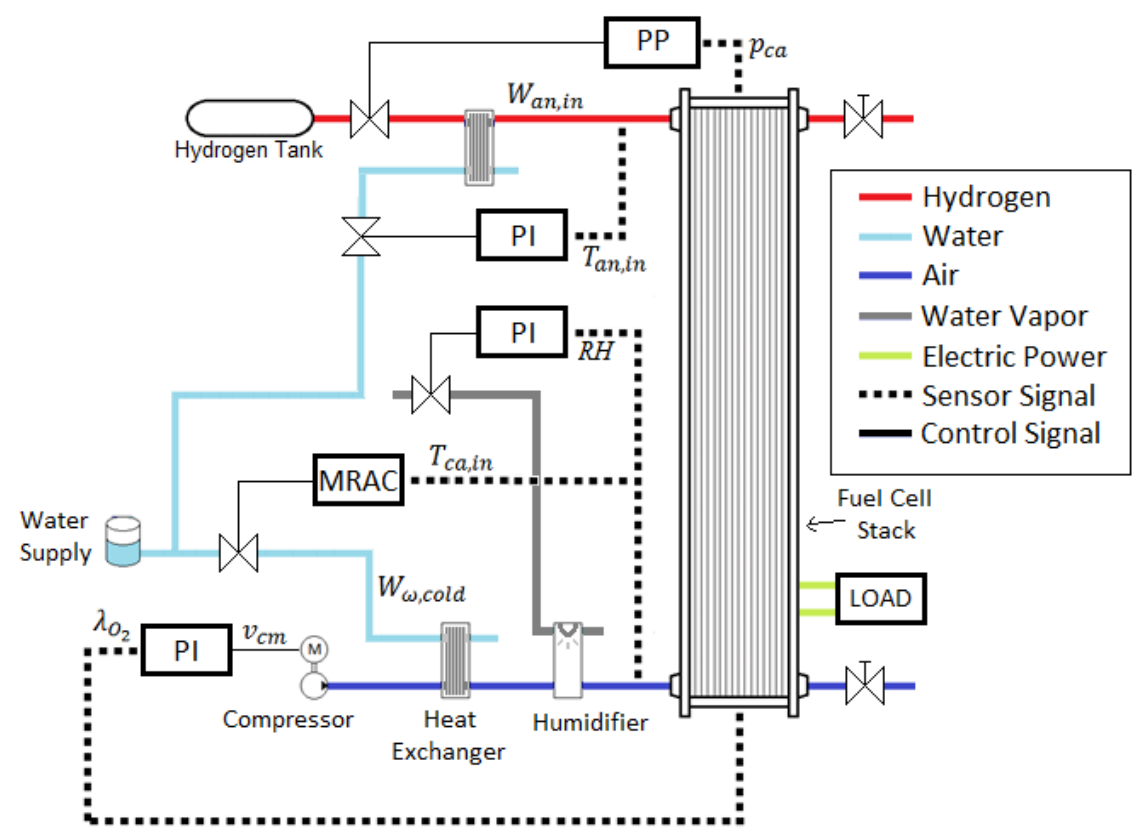

Figure 1. Process diagram flowsheet of the PEMFC system with their respective control loops.

The emphasis is on introducing a practical framework for assessment of the control performance in the reactants supply subsystem, given that:

(1) The controllers performance evaluation is made in terms of the interactions and constrains imposed by the auxiliary equipment; thereby preventing unsafe or degraded operating conditions.

(2) The operating condition definition and sizing of the auxiliary equipment is made in accordance with the PEMFC capabilities.

(3) The static and dynamic characteristic responses of the auxiliary components are captured in the simulator.

(4) The simulator facilitates control tests under changes in the system inputs, disturbances and parametric variations. 
The aspenONE ${ }^{\circledR}$ was selected as the process simulation platform because this software includes unit operations modeling blocks, dynamic simulation tools and own libraries programming facilities, it is used for academic purposes and in industry projects, counting a number of plant operating challenges. Moreover, it can be interfaced to the Matlab/Simulink platform, enabling the use of control tools and toolboxes.

\section{Dynamic Simulation of the PEMFC System}

\subsection{Operation and Simulation of the PEMFC}

The operating principle of a mono-cell is shown in Figure 2. The process begins with the hydrogen and oxygen supply at fixed temperature and pressure. Hydrogen is uniformly distributed through the flow channel for reaching the fuel cell anode, and the air supplied by a compressor enters through the distribution channels of the cathode.

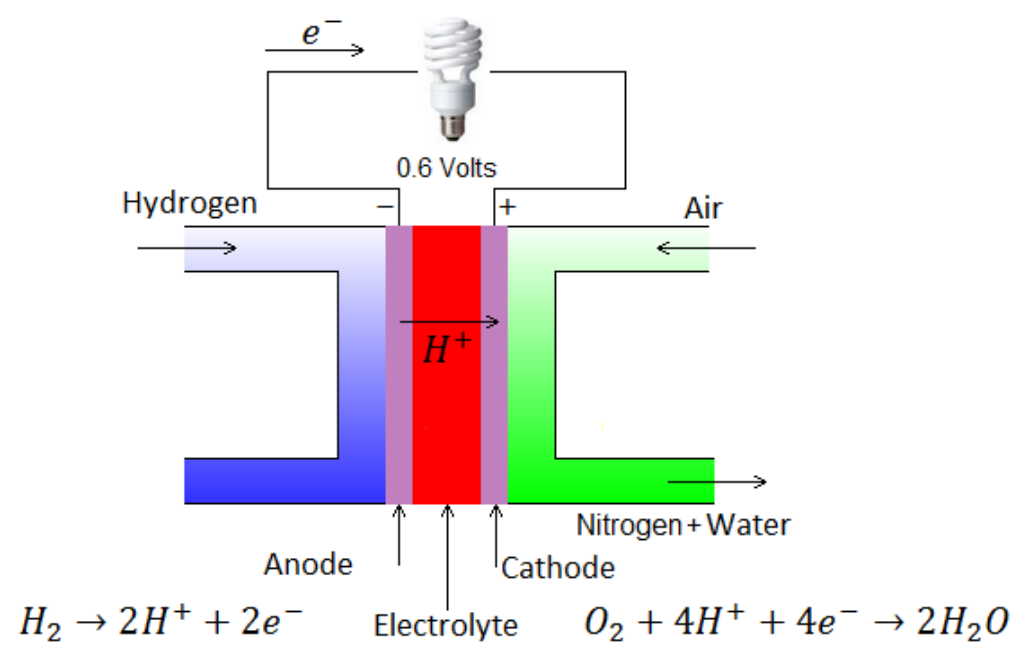

Figure 2. PEMFC operation scheme (Adapted from Wikimedia Commons, Autor Handige Harry).

At the anode, the molecules of $H_{2}$ are diffused through the pores of the electrodes until reaching the catalytic layer where they are linked to the catalyst, then the molecules are dissociated into atoms. That is, molecular hydrogen $\left(H_{2}\right)$ is converted into protons $\left(H^{+}\right)$and electrons $\left(e^{-}\right)$by the oxidation reaction occurring at the anode. $\mathrm{H}^{+}$ions migrate through the electrolyte by jumps. These ions are temporarily attached to negatively charged radicals, contained in the electrolyte membrane; then, these ions are detached and dragged to the cathode by the water contained in the mono-cell. This mechanism gives the name to this type of fuel cell, since proton $\mathrm{H}^{+}$exchange occurs between the electrodes throughout the membrane. On the other hand, electrons are conducted through an external electrical circuit for powering a load. The electron current is the main product of the fuel cell. In parallel, mechanisms that occur at the cathode are: $\mathrm{H}^{+}$ions migrate to the cathode through the membrane, the electrons arriving there by the external circuit, and oxygen molecules $\mathrm{O}_{2}$ transported to the surface are linked to the catalyst to form water by a reduction reaction. Water is a by-product, together with the heat caused by the exothermic reactions. A mono-cell generates a voltage not greater than $1.23 \mathrm{~V}$, and it typically is lower than $1.0 \mathrm{~V}$, whereas a set of mono-cells electrically connected in series provides a greater voltage and the power required by the load, this arrangement forms the fuel cell stack.

The performance of a fuel cell stack is determined by the current $(\mathrm{I})$-voltage $(\mathrm{V})$ relationship which is measured at the terminals of the fuel cell at constant temperature and pressure. This I-V relationship characterizes the steady state performance of the PEMFC and is known as the polarization curve. The dynamic response is characterized by the double layer capacitance effect (electrical dynamics), transients due to continuous thermal, flow, pressure or humidity changes, among others mechanisms occurring on the fuel cell stack and the auxiliary equipment, which conduct to different I-V paths on 
the polarization curves mapping (at different pressures). In this study, the PEMFC polarization curves of the model proposed by Pukrushpan [7] was used to build the PEMFC library. The mathematical model was programmed in Aspen Custom Modeler ${ }^{\circledR}$ and thereafter it was incorporated as a library into the process flowsheet simulation in Aspen Dynamics ${ }^{\circledR}$. This model considers the performance of a mono-cell; but the stack consists of $n$ mono-cells connected in series, so it is assumed that the voltage losses due to the stack assemblage are negligible and the fuel cell output voltage $v_{s t}$ is calculated using (1):

$$
v_{s t}=n v_{f c} .
$$

The voltage of a mono-cell $v_{f c}$ depends on the thermodynamic voltage or Nerst voltage $E$ at open circuit, as well as the voltage drops or voltage overpotentials due to activation loss $v_{\text {act }}$, ohmic loss $v_{o h m}$, and concentration loss $v_{c o n c}$, which make the process irreversible. The voltage of each single cell $v_{f c}$ is calculated using (2):

$$
v_{f c}=E-v_{a c t}-v_{o h m}-v_{c o n c} .
$$

The PEMFC model is summarized in (1)-(15). With respect to the operating variables, an ideal stack temperature $T_{s t}$ is assumed to be regulated at $80^{\circ} \mathrm{C}, i$ is the current density, $p_{\mathrm{H}_{2} a n}$ and $p_{\mathrm{O}_{2} c a}$ are the partial pressures of hydrogen and oxygen, $p_{c a}$ is the pressure at the cathode, $p_{a n}$ is the pressure at the anode. To estimate the ohmic overpotential, $R_{\text {ohm }}$ is the internal electrical resistance of a mono-cell, $\sigma_{m}$ is the membrane conductivity, $t_{m}$ is the membrane thickness, $\lambda_{m}$ is the membrane water content.

$$
\begin{aligned}
& E=1.229-0.85 \times 10^{-3}\left(T_{s t}-298.15\right)+4.3085 \times 10^{-5} T_{s t}\left[\ln \left(p_{H_{2} a n}\right)+\ln \left(p_{O_{2} c a}\right) / 2\right], \\
& v_{a c t}=v_{0}+v_{a}\left(1-e^{-c_{1} i}\right) \text {, } \\
& v_{0}=0.279-8.5 \times 10^{-4}\left(T_{s t}-298.15\right)+4.308 \times 10^{-5} T_{s t}\left[\ln \left(\left(p_{c a}-p_{\text {sat }}\right) / 1.01325\right)\right. \\
& \left.+\ln \left(0.1173\left(p_{c a}-p_{\text {sat }}\right) / 1.01325\right) / 2\right], \\
& v_{a}=\left(-1.618 \times 10^{-5} T_{f c}+1.618 \times 10^{-2}\right)\left(p_{O_{2} c a} / 0.1173+p_{\text {sat }}\right)^{2}+\left(1.8 \times 10^{-4} T_{f c}-0.166\right) \\
& \cdot\left(p_{\mathrm{O}_{2} \mathrm{ca}} / 0.1173+p_{\text {sat }}\right)+\left(-5.8 \times 10^{-4} T_{f c}+0.5736\right), \\
& v_{\text {ohm }}=i \cdot R_{\text {ohm }} \\
& R_{\text {ohm }}=t_{m} / \sigma_{m} \\
& \sigma_{m}=b_{1} \exp \left(b_{2}\left(1 / 303-1 / T_{s t}\right)\right), \\
& b_{1}=\left(b_{11} \lambda_{m}-b_{12}\right) \text {, } \\
& v_{\text {conc }}=i\left(c_{2} i / i_{\text {max }}\right)^{c_{3}} \text {, } \\
& c_{2}= \begin{cases}\left(7.16 \times 10^{-4} T_{s t}-0.622\right)\left(p_{\mathrm{O}_{2} c a} / 0.1173+p_{\text {sat }}\right) & \\
-1.45 \times 10^{-3} T_{s t}+1.68 & p_{\mathrm{O}_{2} c a} / 0.1173+p_{\text {sat }}<2 \mathrm{~atm}, \\
\left(8.66 \times 10^{-5} T_{s t}-0.068\right)\left(p_{\mathrm{O}_{2} c a} / 0.1173+p_{\text {sat }}\right) & \\
-1.6 \times 10^{-4} T_{\text {st }}+0.54 & p_{\mathrm{O}_{2} c a} / 0.1173+p_{\text {sat }} \geq 2 \mathrm{~atm} .\end{cases} \\
& P_{\text {net }}=P_{s t}-P_{c p} \\
& \lambda_{\mathrm{O}_{2}}=W_{\mathrm{O}_{2}, \text { in }} / W_{\mathrm{O}_{2}, \text { react }}, \\
& \log _{10}\left(P_{\text {sat }}\right)=-1.69 \times 10^{-10} T^{4}+3.85 \times 10^{-7} T^{3}-3.39 \times 10^{-4} T^{2}+0.143 T-20.92 .
\end{aligned}
$$


The values $v_{0}$ and $v_{a}$ depend on the partial pressures of the reactants and the temperature of the stack, $p_{\text {sat }}$ stands for the saturation pressure of water vapor and, together with $v_{0}$ and $v_{a}$ are calculated from nonlinear regression. Particularly, the membrane conductivity varies with the membrane water content and fuel cell temperature, this dependence was determined empirically for Nafion 117 membrane in terms of the model constants, reported also in [7]: $c_{1}=10, c_{3}=2, b_{2}=350$, $b_{11}=0.005139, b_{12}=0.00326$. Conversely, the concentration looses depend on the temperature and the reactant partial pressure, hence, the concentration overpotential was also determined empirically, in this case, in terms of $c_{2}$ and $c_{3}$, with $c_{2}$ subject to the conditional statements of (12). Here, $v_{c o n}$ is determined also by $i_{\max }=2.2$, which is the current density than causes abrupt voltage drop in the concentration region. Finally, the number of mono-cells considered is $n=381, P_{s t}$ is the total power delivered by the cell, $P_{c p}$ is the power consumed by the compressor and $P_{n e t}$ is the net system power delivery. The general stack voltage model takes into account the effect of the operating temperature and pressure. Figure 3 shows the polarization curves and power curves that characterize the steady performance of the PEMFC.

The PEMFC model is formulated based on the material and energy balances in the supply and discharge lines at the anode and the cathode [7]. It is assumed that the fuel cell stack operates at constant temperature and a cooling circuit removes heat from the exothermic reactions. Under load variations, the fuel cell operates in a variable pressure mode between 139.9 and $294.7 \mathrm{kPa}$; the polarization curves in this pressure range are observed in Figure 3. Variable-pressure operation is typically carried-out with a blower (lower power systems) or a compressor (higher power systems), but the anode and cathode pressures should be in equilibrium.

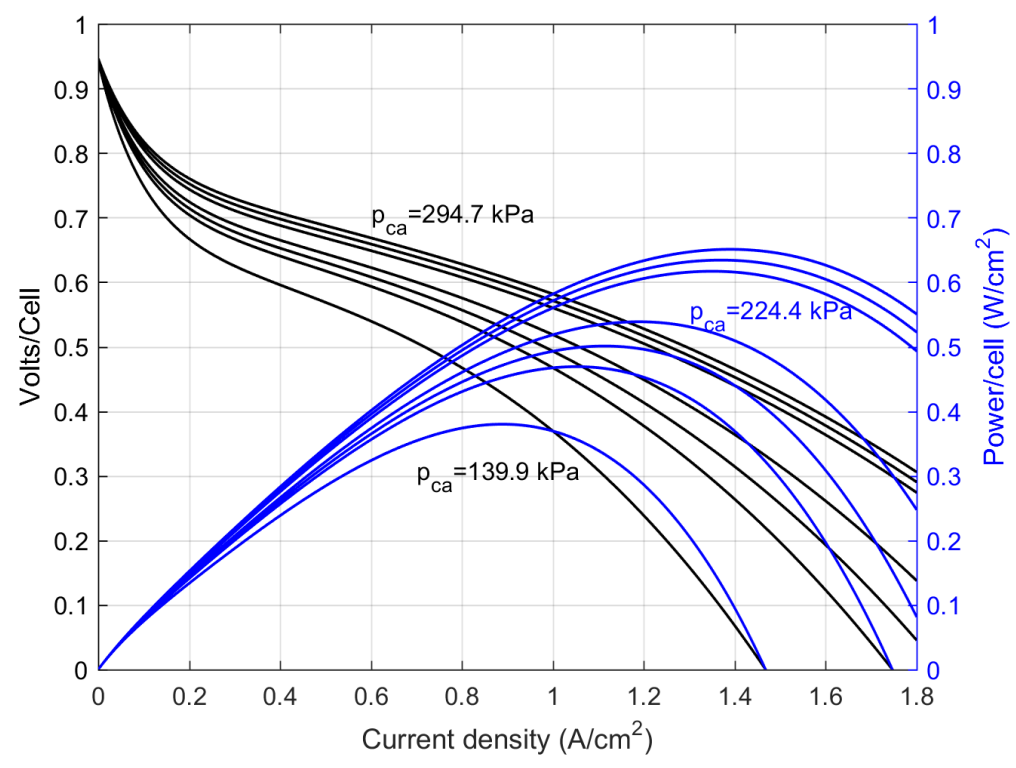

Figure 3. Fuel cell polarization and power curves.

\subsection{Design and Simulation of the PEMFC BOP Components}

The performance of a fuel cell is determined by the polarization curves, the electrical efficiency and the power curves. The equipment included in the simulator was sized and specified with a basis on these performance features. A special emphasis is on the air supply management, since the fuel cell aging is directly related to the air flow rate condition. In effect, oxygen starvation is attributed among others, to factors such as insufficiency in oxygen supply due to sudden increases in power requirements, non-uniform oxygen distribution or poor control of anode and cathode pressure equilibrium [46]. A further difficulty taking place at the cathode if oxygen is depleted is that proton $\left(\mathrm{H}^{+}\right)$reduction occurs instead of oxygen reduction [47]. Successive oxygen starvation or depletion processes may produce permanent damage or degradation of the fuel cell, which contributes to the reduction of its 
lifetime. These problems are closely handled with the air supply management and control tasks and some solutions are treated in the control scheme evaluation section.

The oxygen required by the fuel cell is provided by the air supply of an Allied Signal centrifugal compressor, whose operation is represented by performance curves or characteristic curves gathered in a compressor map [48]. The characteristic curves reflect the correlation between the compression ratio (outlet pressure/inlet pressure), and the air mass flow that the compressor delivers (Figure 4).

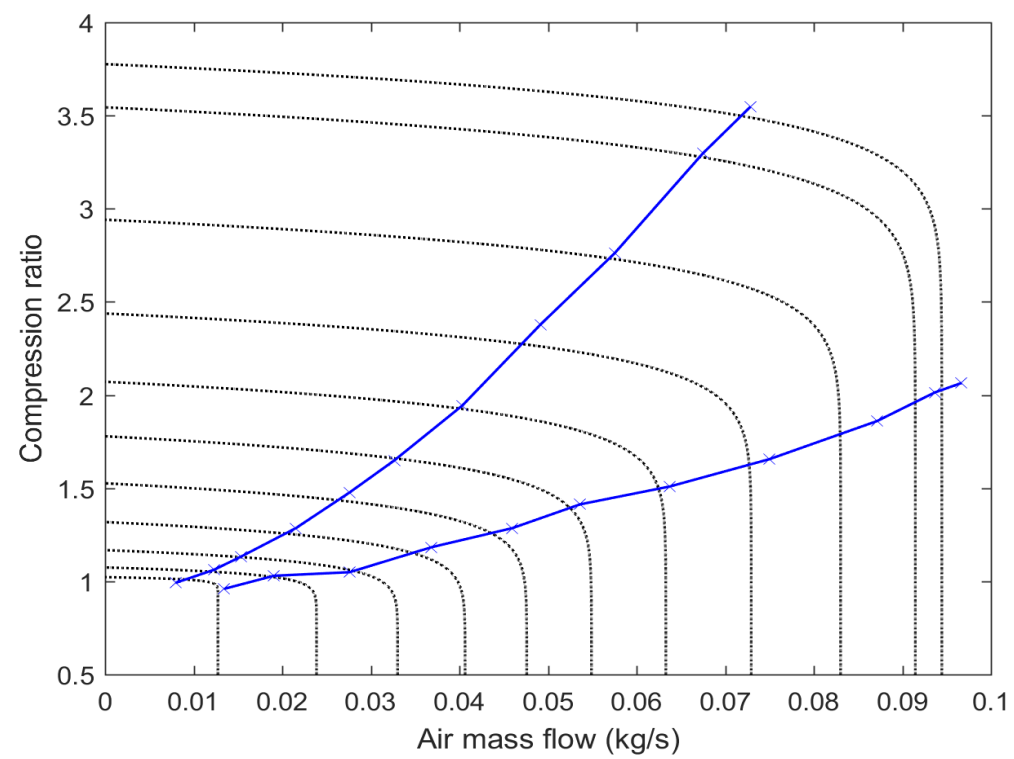

Figure 4. Performance curves of the centrifugal compressor.

The left boundary is the surge line defining the minimum flow limit, at which, for a given speed, the compressor becomes mechanically unstable; whereas the right boundary is the choke or stonewall line, defining the maximum flow that the compressor can deliver. The areas encountered out of these boundaries marked with blue lines in Figure 4 represent the conditions at which problems of pumping and detachment arise. When the air flow is below the surge limit, flow reversal occurs, then noisy and vibrating operation leads to mechanical damage. If the flow is supersonic (the gas velocity is higher than the sound velocity), then, the air demand becomes greater than the compressor capacity. Therefore, the described boundaries outline the compressor capacity and the operating area, free of mechanical instabilities.

The compressor efficiency (Figure 5) is also determined by the pressure ratio and the mass flow, its maximum value is $80 \%$. The region marked in yellow is the most efficient zone and defines the conditions of mechanical stability.

The simulation of the compressor in Aspen Plus ${ }^{\circledR}$ was done using the COMPR modeling block that includes an isentropic compressor model. The parameter that determines the feasibility of approximating a real process with an idealized process is the isentropic or adiabatic efficiency. The COMPR module calculates the discharge conditions from the performance and efficiency curves; therefore, these must be introduced in the module COMPR. The compressor operates with a mechanical efficiency of $80 \%$. The maximum current demand that the fuel cell can tolerate corresponds to an air flow demand of $0.0815 \mathrm{~kg} / \mathrm{s}$; under these conditions, the compressor operates at 100,000 RPM and the air comes out at a temperature of $173^{\circ} \mathrm{C}$.

On the other hand, at small air flows, the compressor operates close to the surge limit, loosens the capacity of increasing the outlet pressure, becomes unstable (Figure 4), and the efficiency is considerably reduced (as it can be seen in Figure 5). Taking into account these drawbacks, the PEMFC system is not able to operate at small flow rate conditions, consequently, the simulation of the PEMFC BOP cannot be conducted at startup conditions or under small flow conditions. Although the PEMFC electric 
performance could operate a wider range of action, the compressor capacities limit the power delivery range. In addition, extremely low reactant flow rate into the fuel cell leads to water evaporation and flooding shifts to the cathode input and likely to air starvation, which in turn, yields undesired output voltage transients and fuel cell performance degradation [46]. These difficulties confirm the necessity of operating in an intermediate range of air flow rate, or equivalently, an intermediate current range in the fuel cell.

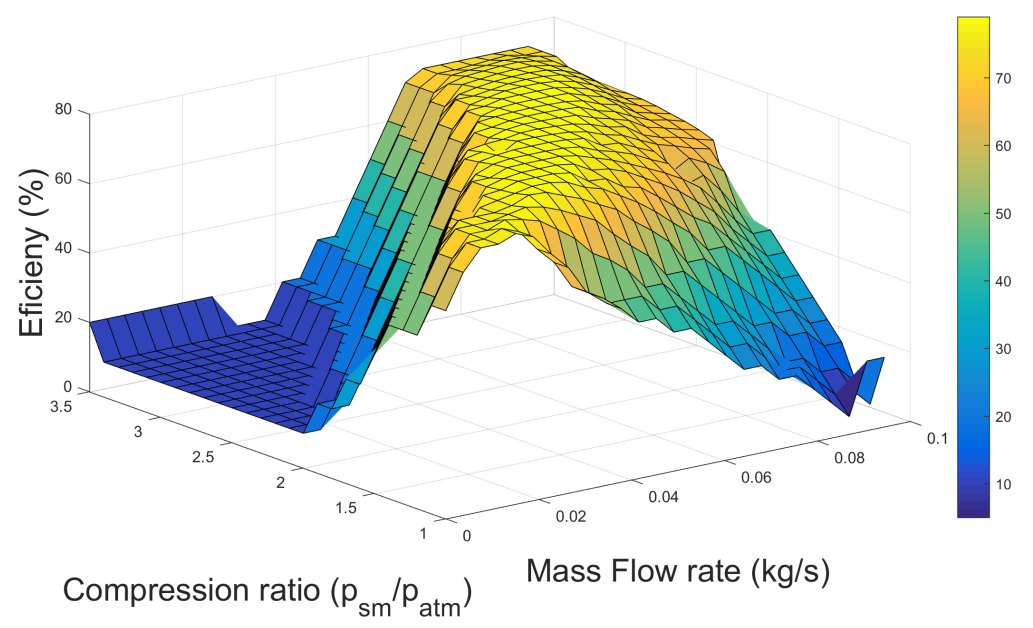

Figure 5. Compressor efficiency as a function of pressure ratio and mass flow.

Heat exchangers modify the temperature of the air delivered by the compressor and the temperature of the hydrogen feeding the fuel cell from a pressurized tank; so that the gases can reach the nominal operating temperature of the fuel cell stack. Two tube and shell heat exchangers were sized with the aid of the module Aspen Exchanger Design and Rating ${ }^{\circledR}$.

The gas flow to treat, the operating pressure and the temperature gradients in heat exchangers are determined at every time by the voltage-current variation in the PEMFC terminals and by the compressor dynamic response. Accordingly, the specification of the input streams is necessary to correctly size heat exchange equipment and then to model it in the process flowsheet. The heat exchanger at the cathode side was specified for a maximum input air flow of $0.0815 \mathrm{~kg} / \mathrm{s}$ at $173{ }^{\circ} \mathrm{C}$ and 3.5 bar, while the heat exchanger at the anode side was sized for changing the temperature of a maximum hydrogen flow of $0.0484 \mathrm{~kg} / \mathrm{s}$, entering at $104{ }^{\circ} \mathrm{C}$ and $3.5 \mathrm{bar}$. In both cases the cooling fluid is water, circulating at $25^{\circ} \mathrm{C}$ and 3.5 bar.

The main issues of the geometric design from Aspen Exchanger Design and Rating ${ }^{\circledR}$ are provided in Table 1. The heat transfer areas are $0.2419 \mathrm{~m}^{2}$ and $0.2742 \mathrm{~m}^{2}$ for the air and hydrogen heaters, respectively. The simulation of the heat exchangers was done in Aspen Plus ${ }^{\circledR}$ using the HEATX module that offers rigorous modeling for shell and tube heat exchangers, with accurate thermal and hydraulic prediction, and establishes the thermodynamic conditions of phase changes if necessary. The design parameters of Table 1 were introduced in the modeling library to simulate the steady state performance; afterwards, the dynamic simulation was carried out in the Aspen Dynamics ${ }^{\circledR}$ platform, including into the flowsheet the rest of the PEMFC BOP components.

The humidifier simulation was simplified using the MIXER module, the modeling block simulates an adiabatic mixer that combines multiple streams into one. It is a rough representation of the humidifier. To saturate the air with water, an air stream is combined with a water vapor stream, so that the humidity controller furnishes instantaneously the necessary vapor content to the oxygen entering into the fuel cell stack, but does not consider the thermal or diffusive transport dynamics; however, the applied humidity controller action prevents the dehydration problem. On the other hand, the fuel cell flooding affects mass transport and produces greater concentration losses, predominantly at the cathode. Excess of water obstructs the pores of the gas diffusion layer and significantly reduces the 
transport rate of the reactants to the catalysts active sites. As a final consequence, flooding leads to starvation and greater potential drops. The considered voltage stack model includes to some extent the flooding due to the stack pressure increase, since the ohmic and the concentration overpotentials depend on the water content (14) and on the stack pressure (11)-(15), respectively. Nevertheless, the simulation results are not analyzed with respect to voltage variation due to the fuel cell flooding; since a water balance derived from basic principles of gas-phase transport is needed to enable the analysis of the effect of the water flooding in the cathode.

Table 1. Heat exchangers design specifications.

\begin{tabular}{lcc}
\hline \multicolumn{1}{c}{ Parameters } & \multicolumn{2}{c}{ Heat Exchanger } \\
\hline \multicolumn{1}{c}{ Tubos } & Cathode & Anode \\
\hline Number of baffles & 6 & 2 \\
Spacing & $135 \mathrm{~mm}$ & $410 \mathrm{~mm}$ \\
\hline \multicolumn{1}{c}{ Tubos } & Cathode & Anode \\
\hline Number of tubes & 32 & 28 \\
Tube length & $1200 \mathrm{~mm}$ & $1350 \mathrm{~mm}$ \\
Inside diameter & $16.56 \mathrm{~mm}$ & $16.56 \mathrm{~mm}$ \\
External diameter & $19.05 \mathrm{~mm}$ & $19.05 \mathrm{~mm}$ \\
Tube passage & $23.81 \mathrm{~mm}$ & $23.81 \mathrm{~mm}$ \\
Tube pattern & Triangular & Triangular \\
Nozzle diameter & $21.34 \mathrm{~mm}$ & $21.34 \mathrm{~mm}$ \\
\hline \multicolumn{1}{c}{ Breastplate } & Cathode & Anode \\
\hline Inside diameter & $205 \mathrm{~mm}$ & $205 \mathrm{~mm}$ \\
External diameter & $219 \mathrm{~mm}$ & $219 \mathrm{~mm}$ \\
Nozzle diameter & $48.26 \mathrm{~mm}$ & $114.3 \mathrm{~mm}$ \\
\hline \multicolumn{1}{c}{ General } & Cathode & Anode \\
\hline Heat transfer area & $0.2419 \mathrm{~m}^{2}$ & $0.2742 \mathrm{~m}{ }^{2}$ \\
Maximum net heat & $10.4 \mathrm{~kW}$ & $16.7 \mathrm{~kW}$ \\
\hline
\end{tabular}

Valves were included in the simulator, thus the actuators modeling is considered for different control loops. The VALVE module was used to simulate pressure drops in adiabatic valves. This module also calculates the temperature and phase of the output current. The PEMFC BOP simulation was done in the Aspen Dynamics ${ }^{\circledR}$ environment. Figure 6 shows the flowsheet of the open loop system.
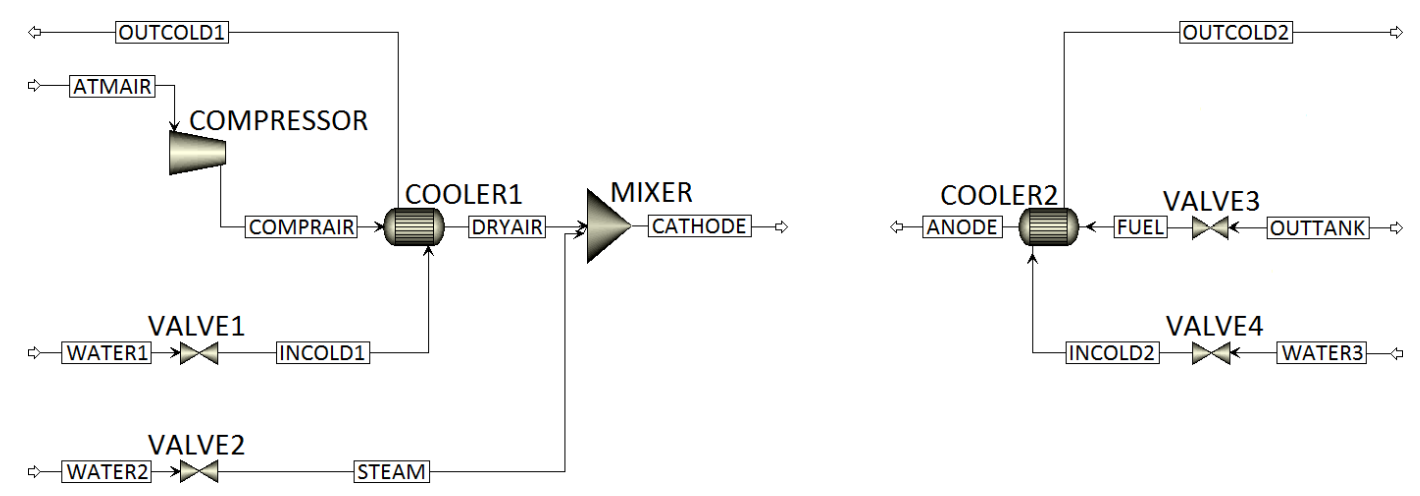

Figure 6. Flow diagram of PEMFC system in Aspen Dynamics ${ }^{\circledR}$.

\section{Control Scheme of the PEMFC System}

The proposed control scheme involves the following control loops (see Figures 1 and 7): The oxygen excess ratio $\lambda_{\mathrm{O}_{2}}$ is regulated with the manipulation of the power supplied to the compressor 
$P_{c p}$; the pressure tracking at the anode $p_{a n}$ is achieved by manipulating the hydrogen flow rate $W_{a n, i n}$, considering the cathode pressure $p_{c a}$ signal as the reference value; the temperature of the reactants entering at the fuel cell stack $T_{c a, i n}$ and $T_{a n, i n}$ are regulated in the heat exchangers with the manipulation of the cooling water flow rate; the relative humidity $\phi_{c a}$ is regulated by varying the flow rate of the water in the humidifier.

Summarizing, the models of the compressor, the heat exchangers, the humidifier as well as the control valves and the PID controllers used in different control loops are available in the simulator libraries, whereas the PEMFC model and the adaptive controller designed to regulate the temperature of the air in the cathode side were programmed in Aspen Custom Modeler ${ }^{\mathbb{R}}$. The resulting libraries are exported to Aspen Dynamics ${ }^{\circledR}$ in order to be integrated in the plant flowsheet.

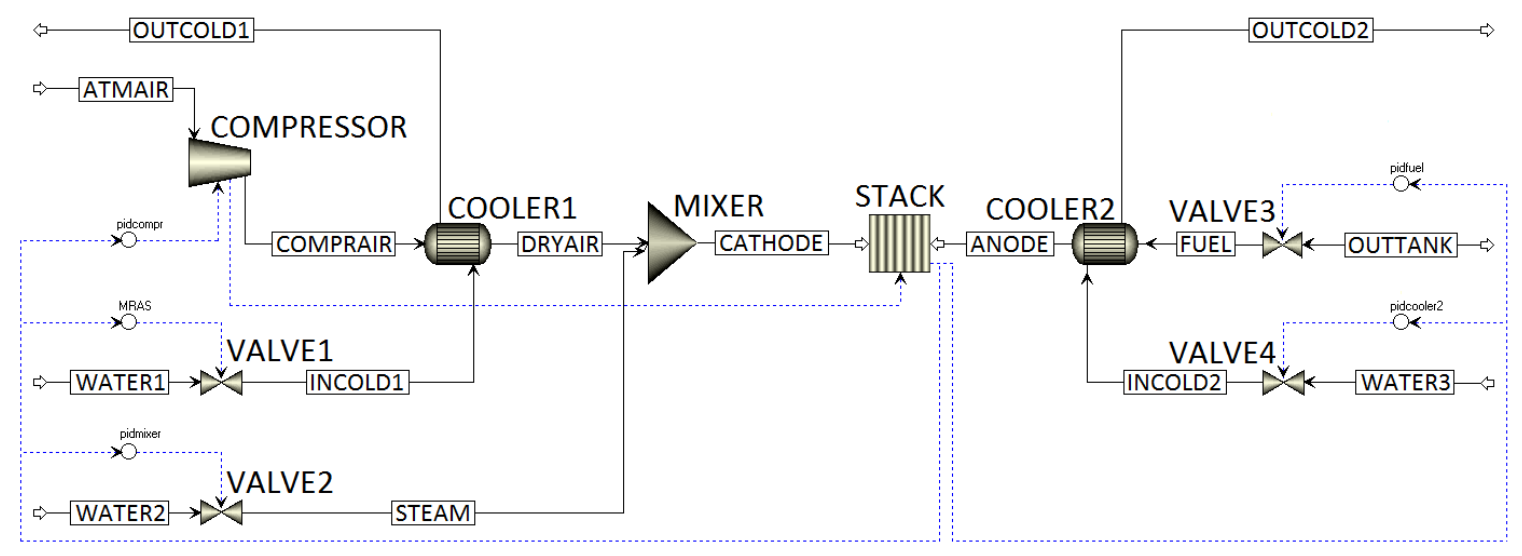

Figure 7. PEMFC control scheme, tested in the simulation environment Aspen Dynamics ${ }^{\circledR}$.

\subsection{Pressure Controller Design for the Anode Side}

Small changes of hydrogen flow rate $W_{a n, \text { in }}$ affect immediately the anode pressure $p_{a n}$. Fluctuating loads are associated to important changes on the hydrogen requirement, specially when the fuel cell operates in variable pressure mode; this is the case of the PEMFC system under study. Herein, pressure differences between the electrodes arise and may produce polymeric membrane breaking. To prevent this problem, it is necessary to minimize the pressure difference between the cathode and the anode areas. The controller objective is the anode pressure $p_{a n}(t)$ tracking to follow the pressure changes at the cathode $p_{c a}(t)$.

A control loop between $p_{a n}(t)$ and $p_{c a}(t)$ is proposed, see Figure 8 . The cathode pressure is the reference, the controller $C(s)$ is a PI and $G(s)$ is the transfer function between the anode pressure $p_{a n}$ and the flow of hydrogen $W_{a n, i n}$.

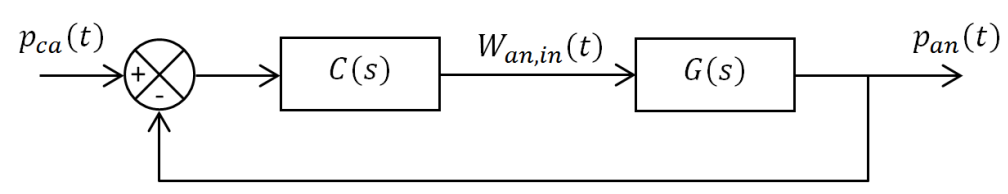

Figure 8. Block diagram of the anode pressure controller.

System identification is used to determine $G(s)$. As the input, a pseudo random binary signal (PRBS), representing $W_{a n, \text { in }}$ variations is applied. Then, the output $p_{a n}$ is recorded. With the input-output data a ARX model structure is estimated by the least square error method, in this case, a first-order transfer function (16) is enough to obtain good fit.

$$
G(s)=\frac{P_{a n}(s)}{W_{a n, i n}(s)}=\frac{3.364 \times 10^{6}}{s+8.032} .
$$


To analyze the dynamics of the anode pressure in function of the hydrogen flow variation, a simulation was done considering variable load (variable $I_{s t}$ ), regulated oxygen excess stoichiometric ratio (regulated $\left.\lambda_{\mathrm{O}_{2}}\right)$ and non-equilibrated pressure condition between the electrodes areas $\left(p_{c a} \neq p_{a n}\right)$ as the initial state. $C(s)$ is a PI controller, $C(s)=K_{p}+K_{i} / s$, then the transfer function in closed loop $p_{a n} / p_{c a}$ is a second order:

$$
\frac{P_{a n}(s)}{P_{c a}(s)}=\frac{C(s) G(s)}{1+C(s) G(s)}=\frac{3.364 \times 10^{6}\left(k_{p} s+k_{i}\right)}{s^{2}+\left(8.032+3.364 \times 10^{6} k_{p}\right) s+3.364 \times 10^{6} k_{i}} .
$$

Because pressure in the anode must follow the pressure in the cathode, then the closed loop steady state gain must be equal to 1 . We choose the pole placement technique to calculate the controller in Figure 8. Because the transfer function in a closed loop is modeled as being a second order, we need two poles $p_{1}$ and $p_{2}$. Given the unity gain feedback system, it becomes true that:

$$
\frac{P_{a n}(s)}{P_{c a}(s)}=\frac{p_{1} p_{2}}{\left(s-p_{1}\right)\left(s-p_{2}\right)} .
$$

From (17) and (18) we solve for the gains $k_{p}$ and $k_{i}$ as follows: $k_{i}=p_{1} p_{2} / 3.364 \times 10^{6}$ and $k_{p}=-\left(p_{1} p_{2}+8.032\right) / 3.364 \times 10^{6}$. One can remark that both gains are divided by $3.364 \times 10^{6}$, thus it is expected to obtain gains with small values. On the other hand, small gains compensate the high steady state value derived from the relationship between anode pressure and hydrogen flow rate (16), $\left(4.188 \times 10^{5}\right)$.

In order to select the poles, it should be considered again that the PEMFC works with variable pressure. Therefore, it is advisable to be prudent, and not significantly modify the natural dynamics produced by the pole at 8.032 , so $p_{1}=10$ is selected, just a little bit faster. The second pole $p_{2}$ should not intervene significantly, for this reason it is placed as far as possible; on the other hand its distance is proportional to the gains $k_{p}$ and $k_{i}$. With this in mind, $p_{2}$ is chosen far enough to have small values of $k_{p}$ and $k_{i}$, but manageable yet, $p_{2}=340$. Thus $k_{p}=1.0166 \times 10^{-4}$ and $k_{i}=0.001$.

\subsection{Air Temperature Controller Design for the Cathode Heat Exchanger}

The temperature of the air at the cathode side and the temperature of hydrogen at the anode side are regulated to the fuel cell operating temperature $\left(80^{\circ} \mathrm{C}\right)$ in order to prevent damage to the polymeric membrane; this is achieved by varying the cooling water flow rate in the heat exchangers.

Due to the nonlinear dynamics of heat exchangers, and because the air delivered by the compressor at the cathode side exhibits significant temperature fluctuations, it could be advantageous to use an adjustable controller, then a Model Reference Adaptive Control (MRAC) is proposed to regulate the air temperature. The idea is to have a closed loop controller with parameters that can be updated by an adjustment mechanism that compares the output of the plant with a model.

The MRAC is built as follows: The correction signal is the error between the temperature of the output stream in the air heat exchanger simulator and the output of the reference model. Since this is a regulation loop, the second signal is a constant of $80^{\circ} \mathrm{C}$ and the error becomes $e(t)=T_{c a, i n}-80$. The control signal is the cold water flow through the jacket of the heat exchanger $W_{\text {incold } 1}$, it is composed of a feedback part, with a setting parameter $\theta_{2}$ multiplied by the temperature in the cathode $T_{c a, i n}$, and another feedforward part with a setting parameter $\theta_{1}$ multiplied by the reference, $W_{\text {incold } 1}=80 \theta_{1}+\theta_{2} T_{c a, i n}$. The parameters $\theta$ are adjusted with the MIT rule, the gradients are calculated with the partial derivatives of the error with respect to the parameters $\theta$. As mentioned before, there is not a model for $\theta_{1}$ because it is a regulation loop, conversely, for $\theta_{2}$ a first order model (19) with unitary state stable gain is used.

$$
\left[\begin{array}{l}
\frac{\mathrm{d} \theta_{1}}{\mathrm{~d} t} \\
\frac{\mathrm{d} \theta_{2}}{\mathrm{~d} t}
\end{array}\right]=\left[\begin{array}{l}
-\gamma \frac{\partial e}{\partial \theta_{1}} e \\
-\gamma \frac{\partial e}{\partial \theta_{2}} e
\end{array}\right]=\left[\begin{array}{c}
-80 \gamma e \\
-\gamma e \frac{a_{m}}{s+a_{m}} T_{c a, i n} .
\end{array}\right]
$$


Afterwards, the cathode temperature control is set up as in Figure 9. The first order model is adjusted by translating the time constant of the response measured in the plant, into a change of $T_{c a, i n}$, as a result of the manipulation of the cold water flow rate $W_{\text {incold } 1}\left(a_{m}=6\right)$. In this procedure, the gain of the controller $\gamma$ is chosen by considering the numerical relationship between the variables in the previous controller (16). In that case, the gain is then small, thus a gain with the same order of magnitude is chosen $\gamma=-3 \times 10^{-6}$.

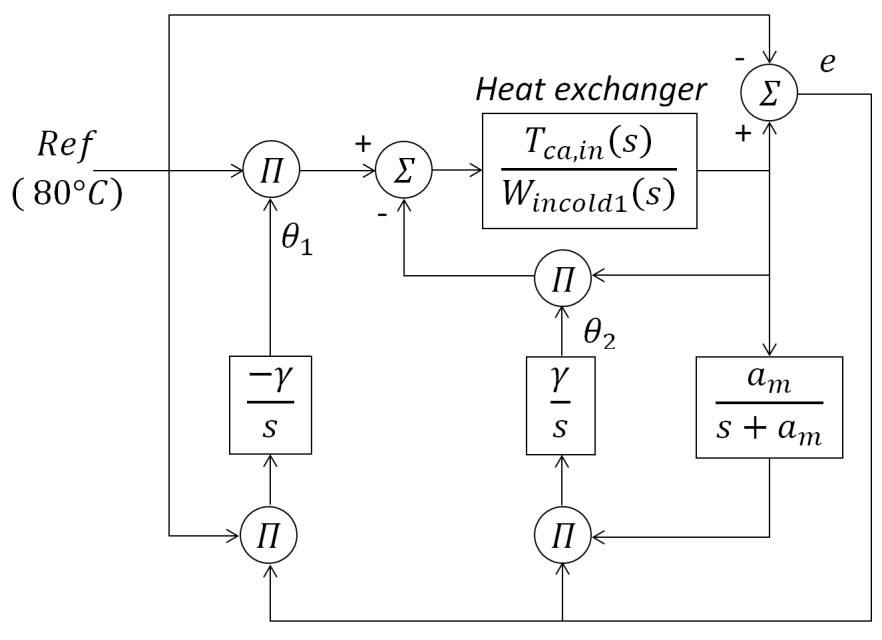

Figure 9. Block diagram of the adaptive controller to regulate the air temperature.

The control tool in Aspen Dynamics ${ }^{\circledR}$ handle only PID controllers. The application of different control techniques must be addressed with external toolbox or developing proprietary libraries. Hence, the adaptive controller was programmed in Aspen Custom Modeler ${ }^{\circledR}$ to create the MRAC library, afterwards, it was integrated into the simulator.

\subsection{Other Regulatory Controllers}

Three additional control loops are necessary, all of them in regulation mode, with no major challenge in their design. To deal with the regulatory control problem, classic PIs were tuned based on the response to a step-type excitation using the methods of Ziegler-Nichols, Cohen-Coon and Chien, Hrones and Reswick (CHR). Subsequently, to confront the various configurations, four performance indices were estimated: the Integral of Squared Error (ISE), the Integral of Absolute Error (IAE), the Integral of Time Multiply Squared Error (ITSE) and the Integral of Time Multiply Absolute Error (ITAE). The preferred configuration was the one leading to the best indices, although slight differences were encountered when comparing the controllers performances.

The first PI controller is configured to regulate the excess oxygen ratio regulation. The oxygen excess ratio $\lambda_{\mathrm{O}_{2}}$ is defined in (14), in this expression $W_{\mathrm{O}_{2} \text {, in }}$ is the oxygen mass flow rate in the fuel cell cathode side and $W_{\mathrm{O}_{2} \text {,react }}$ is the oxygen reacting to produce water at the anode side. According to the stoichiometric balance, $\lambda_{\mathrm{O}_{2}}$ relates the oxygen flow accessing in excess into the cathode with respect to the oxygen required to carry out the reaction. The fact of maintaining $\lambda_{\mathrm{O}_{2}}$ at a value of 2 contributes to the total consumption of hydrogen. The regulation of $\lambda_{\mathrm{O}_{2}}$ at this reference value is subjected to effectively modify the air flow rate by manipulating the compressor power. The selected PI has the gains $k_{p}=3.1 \times 10^{4}$ and $k_{i}=0.03$, deduced by the Cohen-Coon method.

The second PI controller is configured to regulate the heat exchanger anode temperature. Unlike the cathode, the anode feed comes from a hydrogen storage tank, and the intermediate heat exchanger input is subjected to unimportant temperature variations. The chosen PI has the gains $k_{p}=5$ and $k_{i}=2$ deduced by the CHR method. 
The controller to regulate the relative humidity is calculated as the relation between the partial pressure and the saturation pressure of the water steam. The signal error for this control loop was calculated by using (20). Where $y_{\mathrm{H}_{2} \mathrm{O}, c a, i n}$ is the water steam composition at the input of the cathode $p_{c a, i n}$ is the water steam composition at the input of the cathode. The PI has the following gains: $k_{p}=2$ and $k_{i}=10$.

$$
e(t)=p_{s a t}-p_{v, h m}=p_{s a t}-y_{H_{2} O, c a, \text { in }} p_{c a, i n} .
$$

\section{Results and Discussion}

The PEMFC system under study is a Multi-Input Multi-Output (MIMO) dynamical system. The control problem is treated with decoupled controllers; nevertheless, attempts were done to overcome the non-lineal behaviors and interactions between the BOP components and between the various control loops of the system. The control scheme provides a suitable solution to the regulatory and tracking objectives, it should prevent instabilities, damage and degradation or should serve as analysis tool to determine the PEMFC system operating boundaries. Therefore, the control scheme effectiveness is interpreted in that sense from tests carried out with two distinctive load profiles:

(1) The first profile is the same load current used in [7], which consists of progressive increments of current that enables the PEMFC operation over the entire possible voltage-current region. This load profile serves to evaluate the control scheme under operational changes, system disturbances and parametric variations. The proposed tests should evidence that the fuel cell can operate in the safe and efficient region, at the same time that the auxiliary subsystems do.

(2) The second load is a standard driving cycle, $300 \mathrm{~s}$ of the motorway Artemis cycle for maximum speeds of $130 \mathrm{~km} / \mathrm{h}$ (ARTMW130) were considered. The Driving Cycle Simulink Block [49] was used to produce the speed profile, representative of driving conditions. Then, the power load $P_{\text {Motor }}$ was estimated from typical small vehicle characteristics as stated in (21) [50]. Finally, the current demand is deduced from this profile by considering the performance of the PEMFC. The resultant load profile serves to evaluate the control scheme under faster dynamics and covering a different power range with respect to the first load. The proposed tests should highlight the efficacy to attain the regulatory and tracking objectives and should be useful to determine the operating boundaries of the system, based on the performances of auxiliary subsystems.

$$
P_{\text {Motor }}=\left[C_{r} M g \cos (\alpha)+M g \sin (\alpha)+M d V / d t+1 / 2 \rho S C_{x} V^{2}\right],
$$

where:

$V=$ Vehicle speed $(\mathrm{m} / \mathrm{s})$.

$M=$ Vehicle mass $(1000 \mathrm{~kg})$.

$g=$ Gravitational constant $\left(9.81 \mathrm{~m} / \mathrm{s}^{2}\right)$.

$\alpha=$ Road gradient $\left(0^{\circ}\right)$.

$C_{r}=$ Vehicle friction coefficient (0.01).

$C_{x}=$ Aerodynamic coefficient $(0.3)$.

$\rho=$ Air density $\left(1.225 \mathrm{~kg} / \mathrm{m}^{3}\right)$.

$S=$ Front surface $\left(2.5 \mathrm{~m}^{2}\right)$.

\subsection{Tests under Operational Changes}

The first test serves to analyze the performance of the control scheme under changes in the system variables, with special attention to the regulation of the excess oxygen stoichiometric ratio. The load profile consists of progressive increments of current that conduct the PEMFC to operate over the entire possible region (with air flow demands until $0.0815 \mathrm{~kg} / \mathrm{s}$ ). Given a positive load increase, the power consumed by the compressor grows with the oxygen utilization (Figure 10). For a maximum power demand $(65 \mathrm{~kW})$, the compressor consumes about $12 \mathrm{~kW}$, i.e., about $18.5 \%$ of the power generated 
by the PEMFC. Under these conditions, the net power (power produced by the fuel cell-compressor consumption) is reduced to about $53 \mathrm{~kW}$.
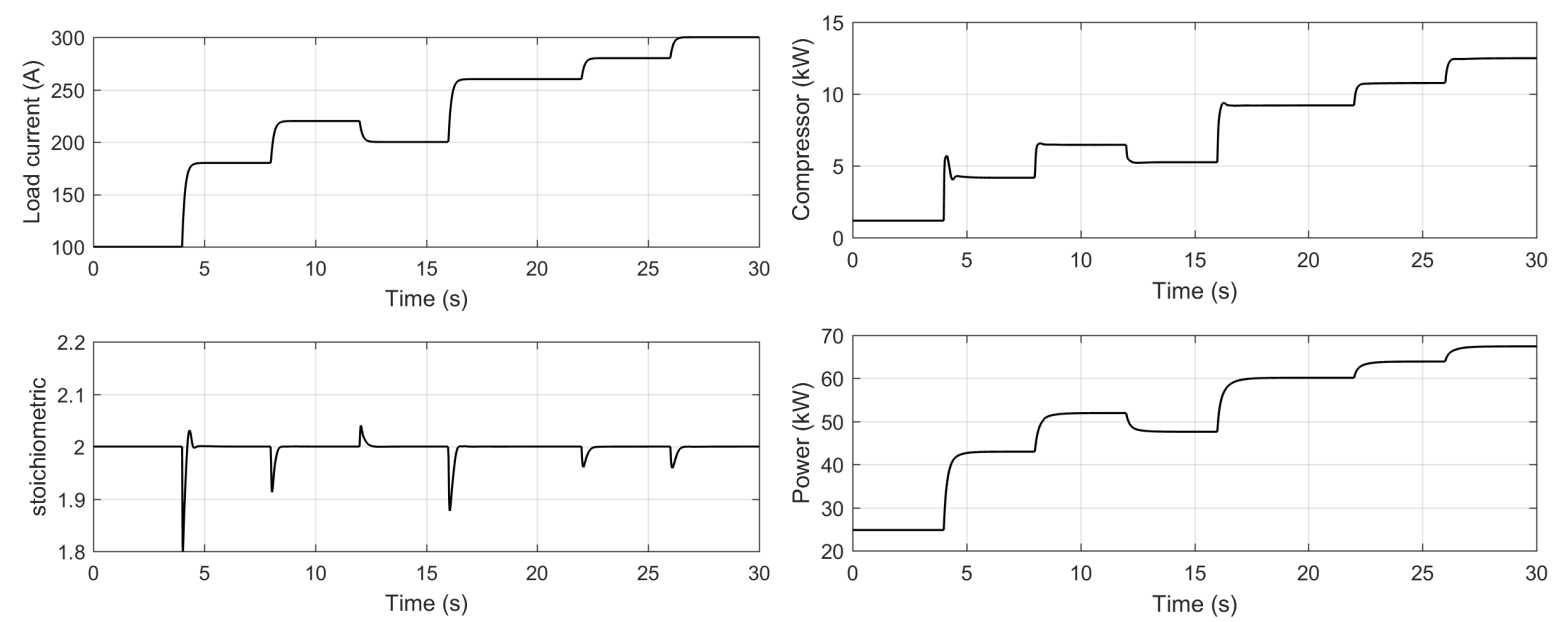

Figure 10. PEMFC simulation with operational changes.

The regulation of the oxygen excess ratio to a value of 2 (Figure 10), successfully conducts the compressor to operate in a flow path-pressure within the zone free of mechanical instability, without exceeding the limits of detachment and pumping (Figure 11).

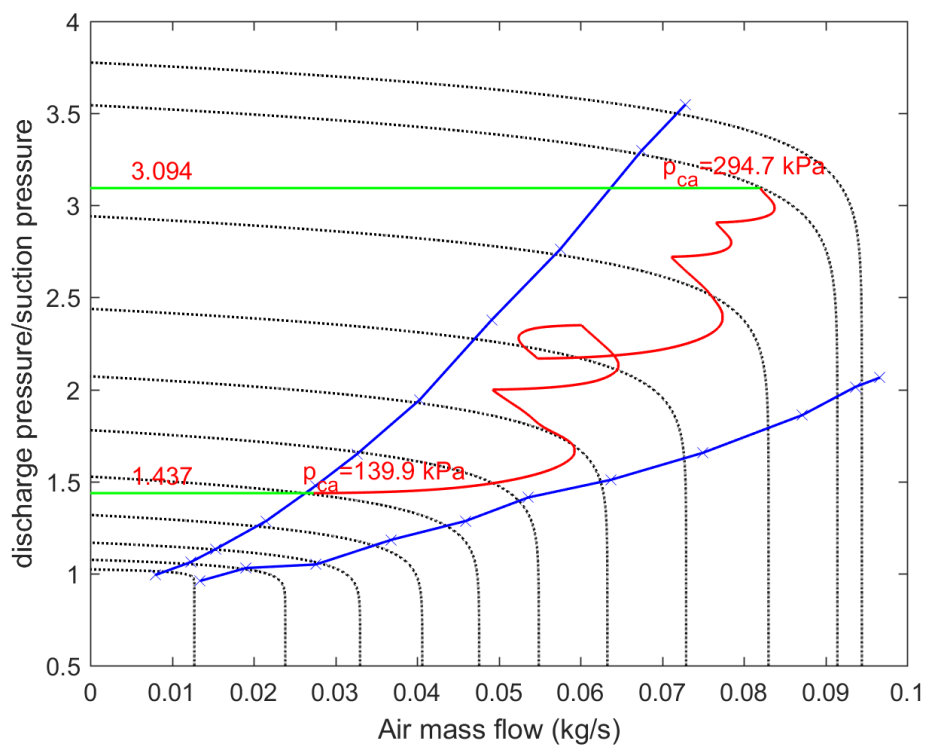

Figure 11. Compressor flow rate-pressure path.

The PEMFC system powers a variable load under isothermal conditions, thereby, the pressure must be modified to guarantee the energy supply. Figure 12 shows the pressure trajectory on the polarization curve of a mono-cell at the nominal fuel cell temperature $\left(80^{\circ} \mathrm{C}\right)$.

It can be seen that the voltage delivered by each mono-cell is around $0.6 \mathrm{~V}$, regardless of the current and power changes. However, the current density covers a range of 0.3 to $1.1 \mathrm{~A} / \mathrm{cm}^{2}$, which corresponds to a large part of the ohmic region, where the operation of the fuel cell is safe. This region has a good balance between efficiency and power, because at lower currents, the power diminish (Figure 3), whereas at higher currents, the efficiency decreases. 


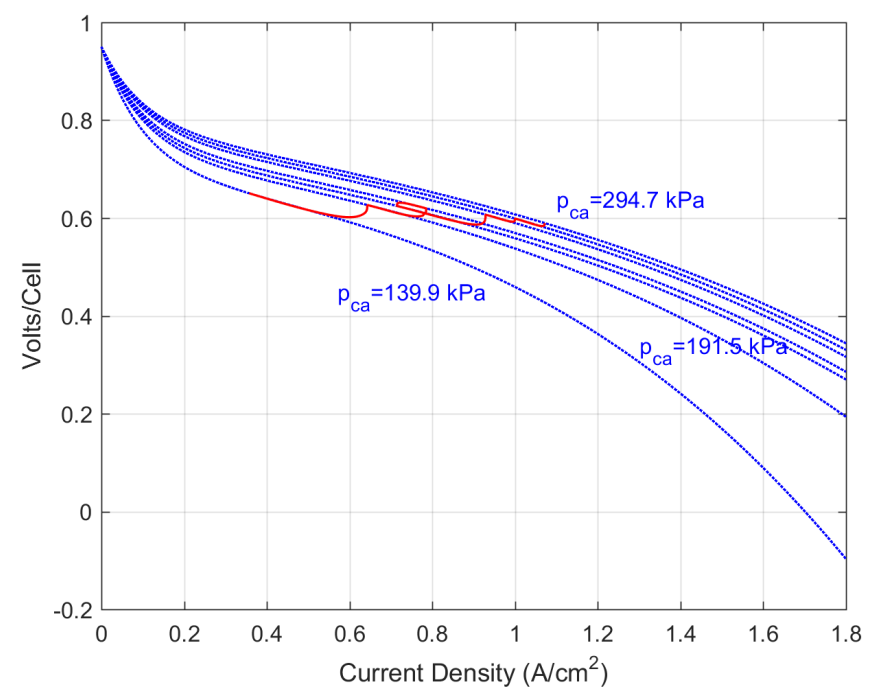

Figure 12. Current-Voltage path on a mono-cell operating at $80^{\circ} \mathrm{C}$ and 139.9 to $294.7 \mathrm{kPa}$.

With the oxygen consumption, the hydrogen utilization increases to follow the cathode pressure variation. The pressure tracking aids to minimize effectively the pressure difference in the electrodes area, although the cathode pressure is modified in a wide range from 140 to $300 \mathrm{kPa}$ (Figure 13).
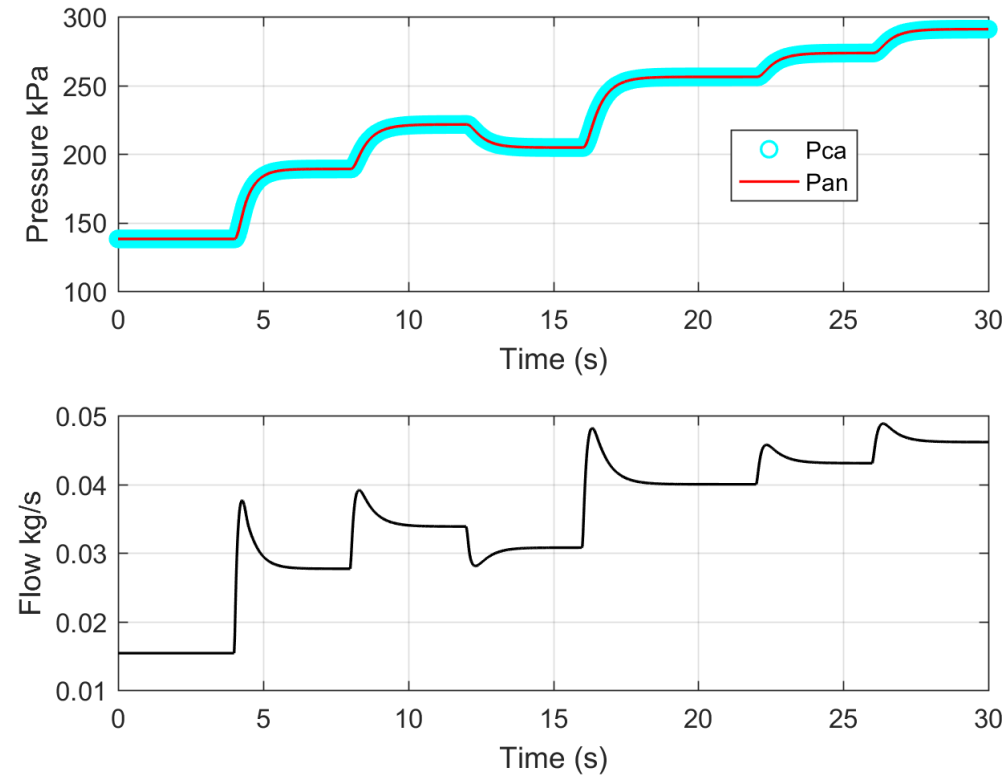

Figure 13. Minimization of the pressure difference between the cathode and anode, manipulating the hydrogen mass flow.

\subsection{Tests under System Disturbances}

The change of temperature in the air delivered by the compressor can represent important perturbations for regulating the temperature of the air entering at the fuel cell cathode (Figure 14). The compressor supplies hot air that reaches until $173{ }^{\circ} \mathrm{C}$ at the highest possible air flow. The adaptive controller regulates properly the air temperature in the cathode inlet without exceeding $0.4{ }^{\circ} \mathrm{C}$ over the reference value of $80^{\circ} \mathrm{C}$ (fuel cell nominal temperature). The controller rejects the disturbances quickly and provides a unitary gain to the regulated variable. 

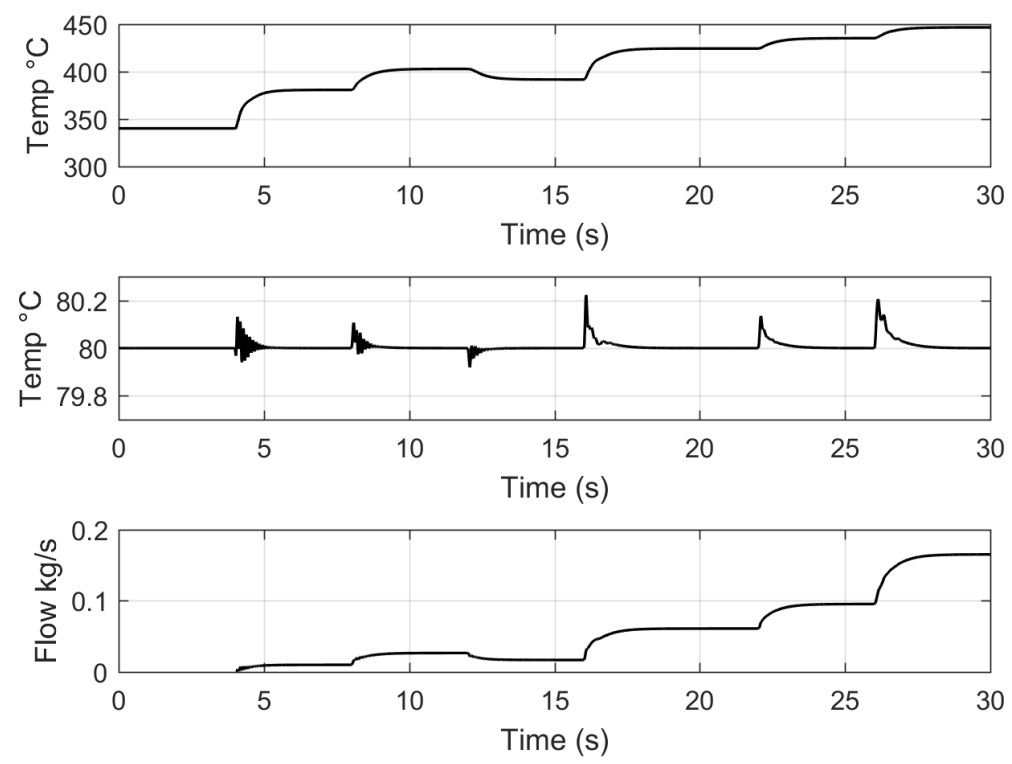

Figure 14. Temperature control air to the cathode inlet, manipulating the flow of cooling water.

In a closed loop, the variation of $0.4{ }^{\circ} \mathrm{C}$ cannot be exceeded, since this value is obtained with the maximum disturbance on the temperature at the compressor outlet (Figure 14) that corresponds to the maximum current demanded by the load (Figure 10). However, if exceeded, there is a risk of affecting the humidification of the reactants, causing dehydration of the membrane because at high stack operating temperatures, the reaction of water formation at the cathode may be insufficient to compensate the lack of water; therefore, the membrane becomes drier and the conductivity decreases, leading to higher ionic resistance and temporary larger ohmic losses. A long-term dehydration condition causes irreversible damage to the membrane and develop cracks, along with gas crossover and hot spots (high chemically active areas due to the exothermic reactions), resulting in more gas crossover. Once this process is initiated, a destructive sequence is established, hence, dry membrane condition conducts to shorter the fuel cell life [47]. The effect of operating the fuel cell with membrane damage is exemplified in Section 4.3. Moreover, the variation of the air flow rate in the compressor can disturb the relative humidity at the fuel cell cathode input. The humidity controller aids to inject enough steam for controlling the relative humidity. Because the model is quite simplified and the control is perfect, the controller performance is not presented here; instead Figure 15 shows the vapor injected to the air stream allowing perfectly humidified air fed.

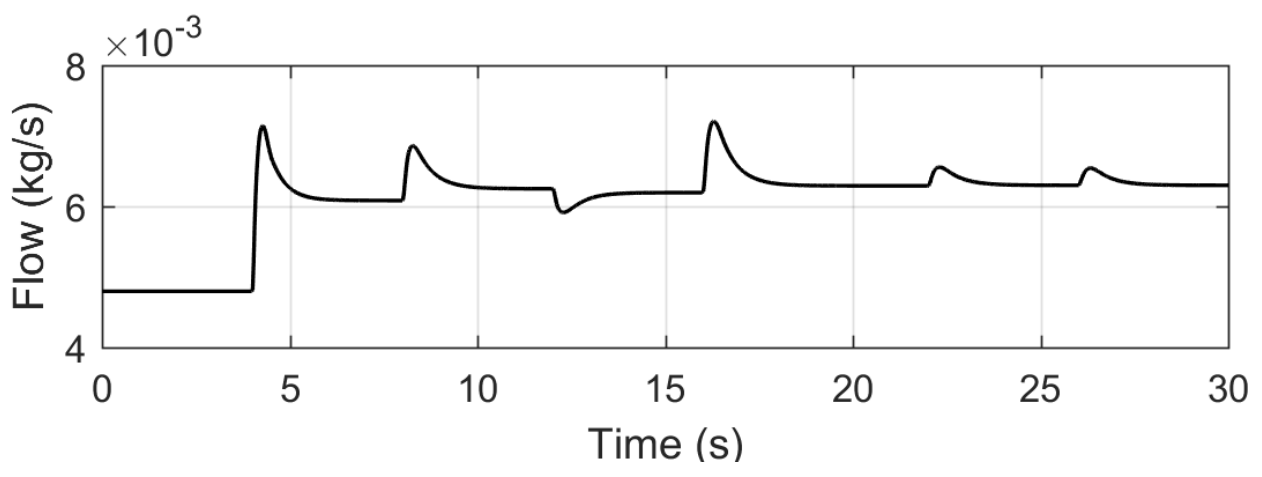

Figure 15. Water vapor injected to the air stream for maintaining humidity saturation condition. Current increasing steps load case. 


\subsection{Test under Parametric Variations}

In order to evaluate the control scheme performance under parametric changes, it is supposed that the polymer membrane is partially damaged, thereby ensuing the system would fail. A reduction of $15 \%$ in the effective area is assumed, i.e., decreases from 0.028 to $0.024 \mathrm{~m}^{2}$.

The simulation shows that the PEMFC system undergoes natural degradation and delivers reduced voltage and power at its terminals (Figure 16); but, the general degraded behavior does not represent a large deviation of the fuel cell normal operation, since the power delivered by the PEMFC does not decrease more than $6 \%$ during the increasing demand of the load, while the regulation of the oxygen excess ratio, effectively allows the compressor to operate with mechanical stability and efficiency despite membrane damage.
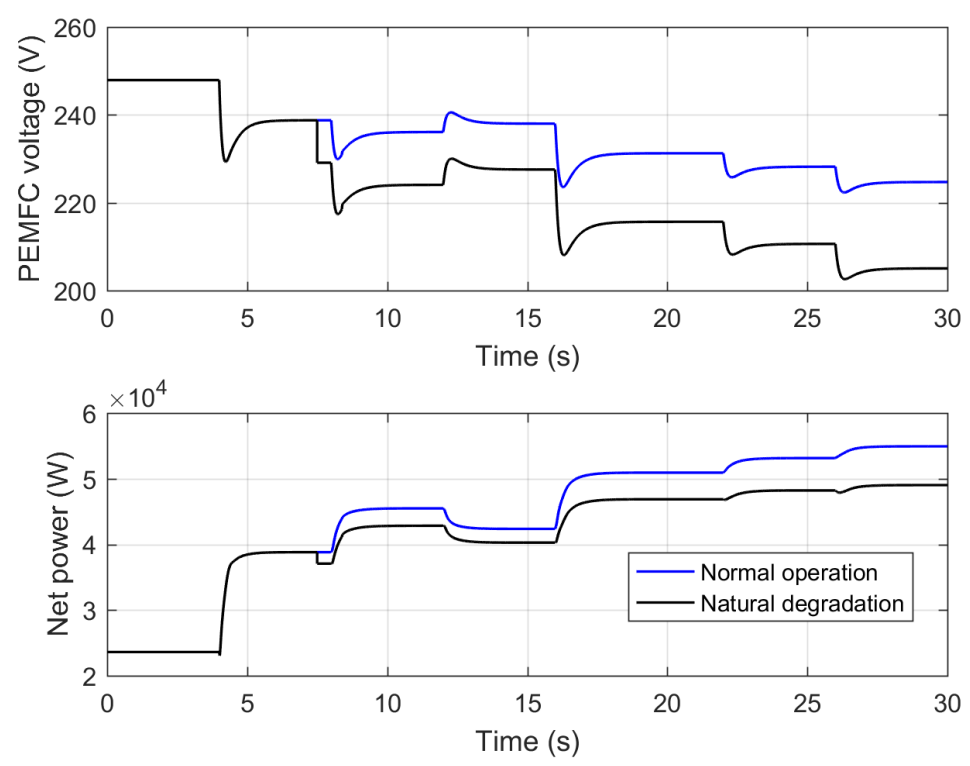

Figure 16. System response to a parametric variation of $15 \%$ in the effective area of the polymer membrane.

\subsection{Test under Driving Solicitations}

The second load profile is representative of a standard driving cycle on the motorway, with maximum speed of $130 \mathrm{~km} / \mathrm{h}$. The mechanical parameters used in (21) to compute the power demand of the vehicle motor $P_{\text {Motor }}$ correspond to the characteristics of a small vehicle. Figure 17 shows the vehicle solicitations in function of the current and the electric power demanded to the PEMFC, which cover span intervals until 200 A or $40 \mathrm{~kW}$, respectively. Control difficulties may come due to low air flow rates or due to fast and fluctuating input dynamics. Nevertheless, the control scheme must provide useful insight to mark boundaries of the PEMFC system applicability.

The anode pressure tracking control was made with the following results: The anode pressure fits perfectly with the cathode pressure during the whole test even though fast current transients and sudden large changes occurs continuously (Figure 18). Consequently, the risk of polymeric membrane breaking diminish considerably. The control effort is minor, since the hydrogen flow rate varies from 0 to $0.03 \mathrm{~kg} / \mathrm{s}$ and still follows the fast dynamics.

The air temperature is properly regulated at $80{ }^{\circ} \mathrm{C}$ as it was the case of the first load considered, whereby the temperature control efficacy was demonstrated (Figure 14). The hydrogen temperature is also regulated around $80{ }^{\circ} \mathrm{C}$; but the transients are significantly smoother in comparison with the air temperature variation because the hydrogen is delivered by a tank, while the air is delivered by a compressor operating with important transients. For this reason, only the air temperature control was presented. Moreover, the air is without difficulty saturated with water, Figure 19 presents the water 
vapor injected to the air stream in order to maintain saturation conditions, the required water content varies with the pressure. To conclude the control strategy test under driving standard conditions, the oxygen excess ratio $\lambda_{\mathrm{O}_{2}}$ control performance is also presented.
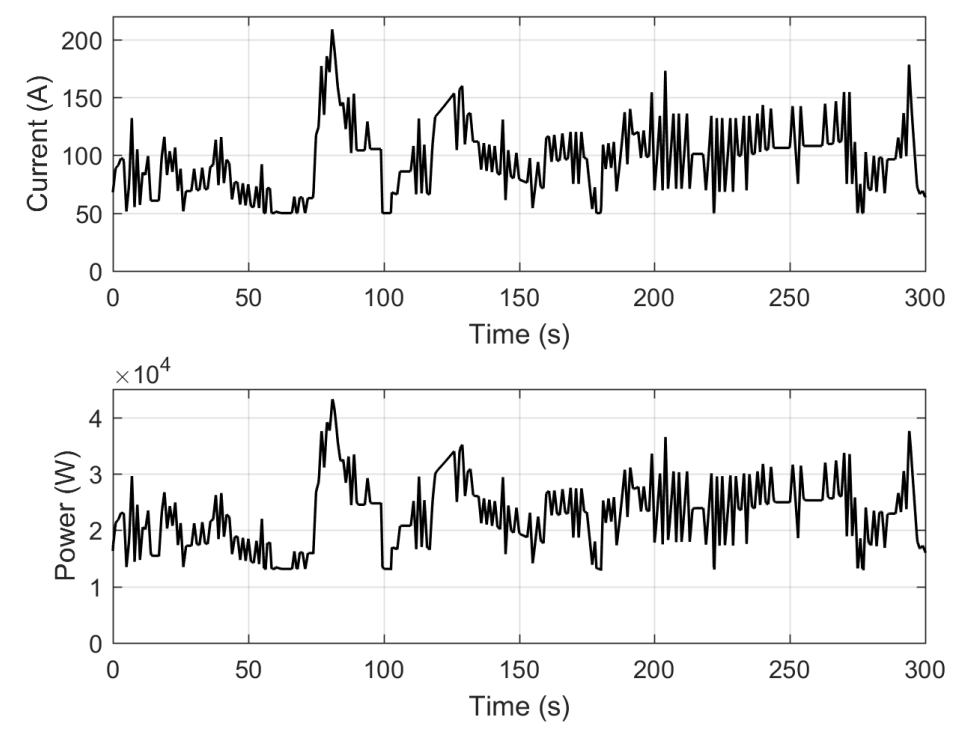

Figure 17. PEMFC power load.
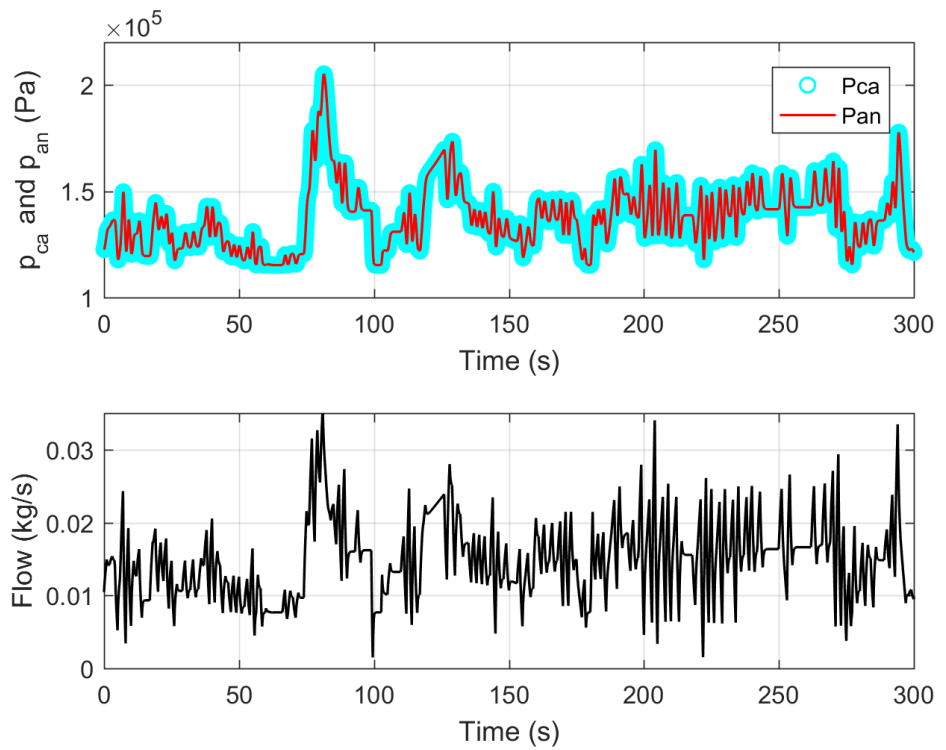

Figure 18. Pressure controller.

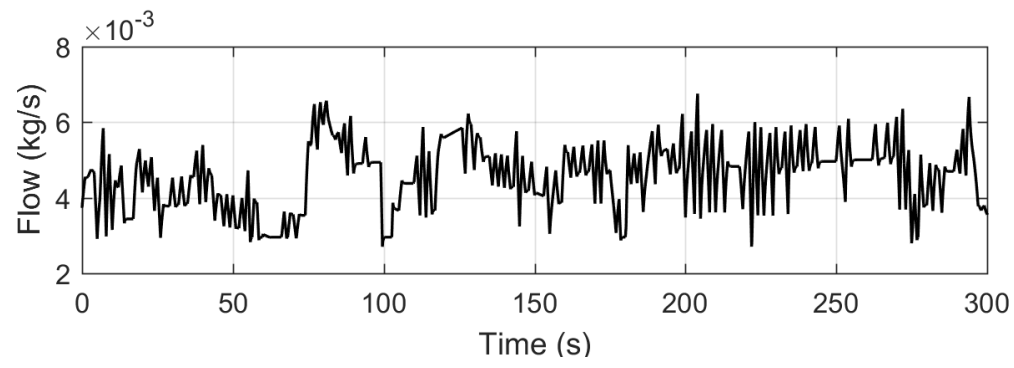

Figure 19. Water vapor injected to the air stream for maintaining humidity saturation condition. Standard driving cycle load case. 
The regulatory control of the stoichiometric oxygen excess ratio is successfully achieved, $\lambda_{\mathrm{O}_{2}}$ is conserved between 1.95 and 2.08, while the control effort defined by the power consumption of the compressor remains largely, close to $2 \mathrm{~kW}$, with variations achieving until $45 \%-48 \%$ of the maximum compressor power capacity (Figure 20).
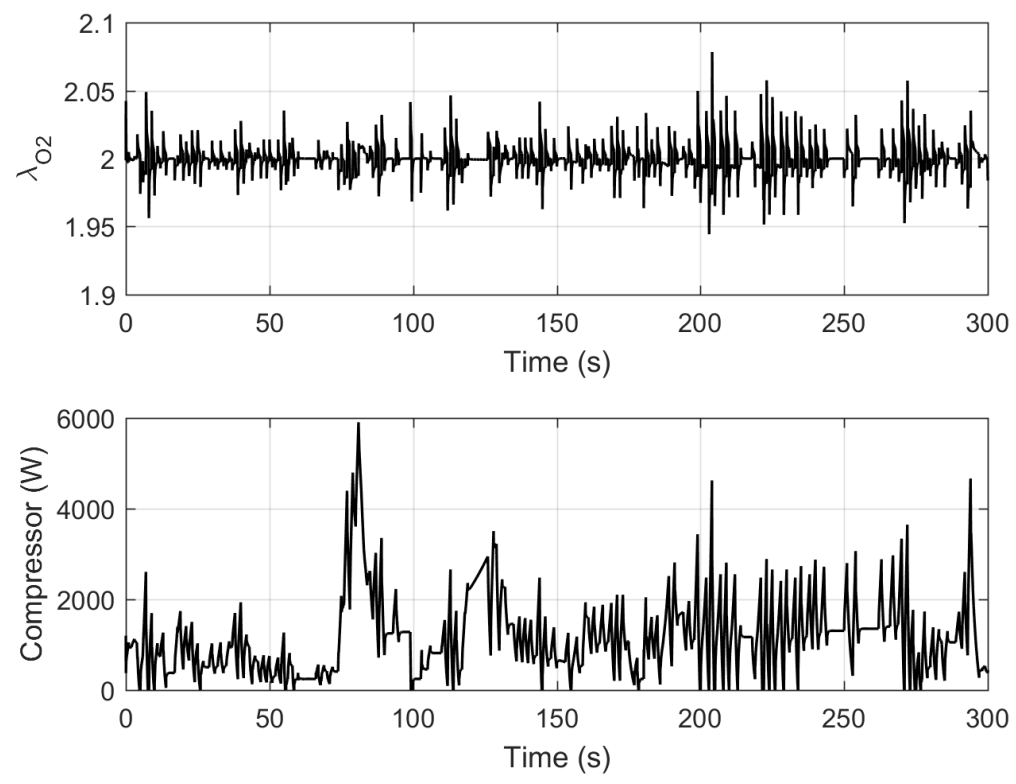

Figure 20. The excess oxygen ratio regulation.

Summarizing, the control scheme contributes to attain the reactants flow rate, temperature, pressure and humidity, needed by the PEMFC stack to supply the load demand. All the control objectives are attained without overshooting or delays; however, further analysis should consider the auxiliary equipment constrains. Figure 21 shows the fuel cell path relating the air flow rate and the compression ratio over the compressor map. During the driving cycle, the flow conditions exceeding the surge limit are low power demands that conduct to the lowest compressor efficiency region. These difficulties arise due to startups and fast changes in the load.

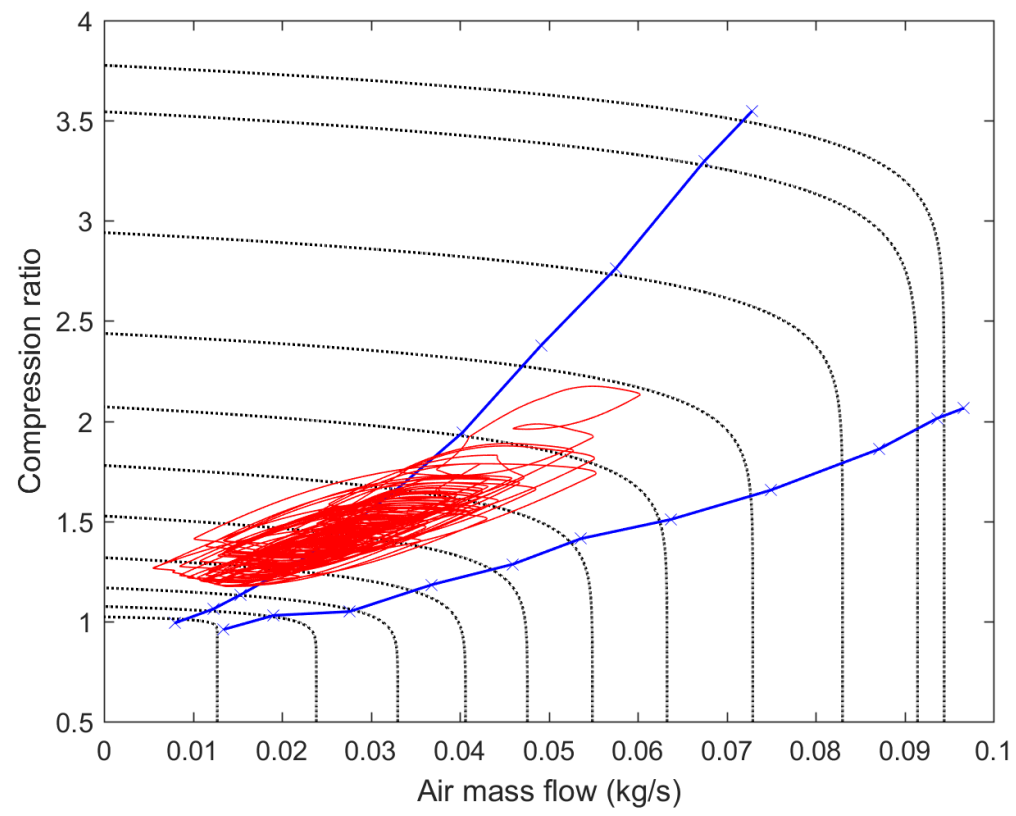

Figure 21. Air compression path conforming to the PEMFC solicitations. 
Clearly, a backup source is mandatory to overcome these difficulties, but an energy management strategy is necessary to determine properly the power split between the sources. The PEMFC operation should be restricted by defining a low power limit to overcome low efficient operation of the compressor, in the vicinity of the surge limit. Figure 22 exhibits the PEMFC operation for solicitations over $100 \mathrm{~A}$, for this current demands, the compressor operates $92 \%$ of the time between the safety limits.

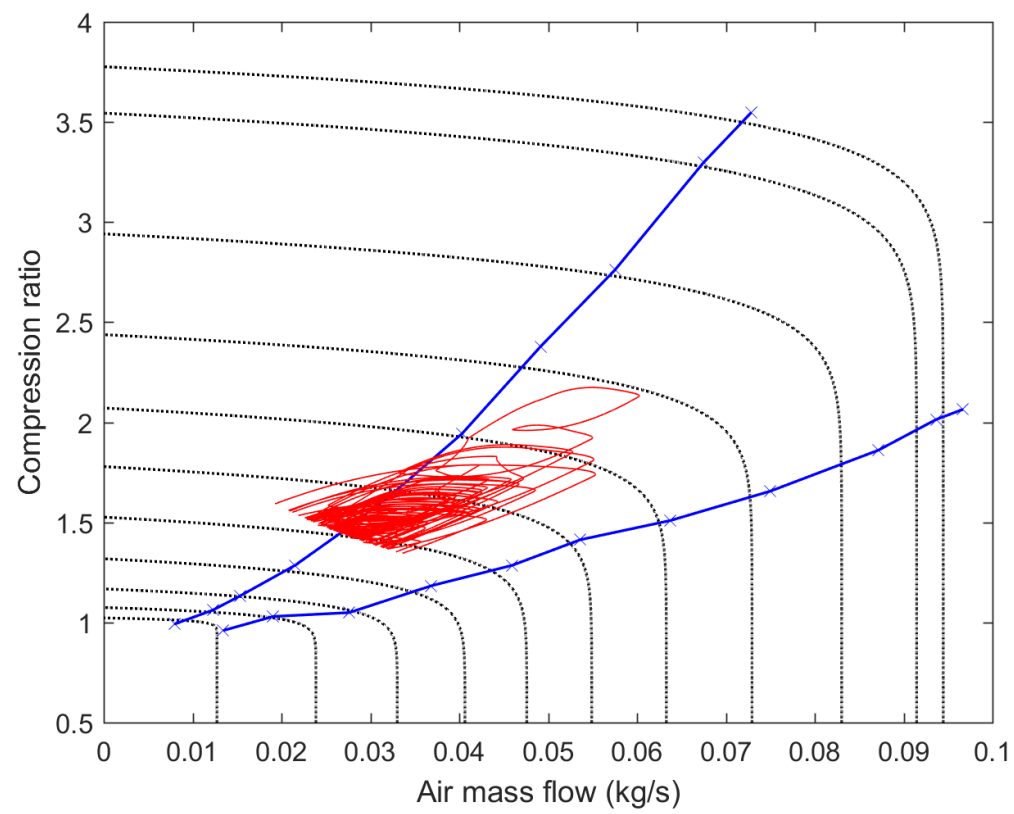

Figure 22. Air compression path for PEMFC solicitations greater than $100 \mathrm{~A}$.

The signals that continue overtaking the surge limits arise due to the fast load transients. Typical energy management strategies consider frequency analysis to determine the dynamic capacity of the fuel cell in order to limit conveniently the the fuel cell intervention.

Considering the tests realized with both current profiles, some concluding issues are that the PEMFC system under study should be limited between 23 to $60 \mathrm{~kW}$, or equivalently from 100 to $250 \mathrm{~A}$. On the other hand, supplementary frequency analysis is mandatory to determine the dynamic capabilities of the fuel cell. The compressor capacity analysis realized herein is often not considered to determine the power split between the sources in hybrid generators. This analysis should improve the power management design, it becomes possible because auxiliary equipment is integrated in the fuel cell system simulator. The contribution may come as it should be expected that dehydration and flooding can be avoided at the same time that air starvation, undesired output voltage transients and fuel cell performance degradation. As it was explained before, special emphasis on the air supply management is important since the fuel cell aging is directly related to the air flow rate conditions, as well as the mechanical instability and damage problems in the compressor.

\section{Conclusions}

The developed simulator of a power generation system combines the models of a PEMFC stack, a compressor feeding the fuel cell stack, two heat exchangers modifying the reactants temperature to attain the anode and cathode sides nominal temperature, and a humidifier saturating with water the air entering into the fuel cell stack. The auxiliary equipment was sized based on the PEMFC performance, using design tools from the simulation environment. In addition, two built libraries served for modeling the PEMFC stack behavior and applying the MRAC control into the air temperature control loop. The air supply control scheme showed effective performance in equilibrating the cathode and 
anode pressure, and for regulating the temperature and humidity of the air and hydrogen input streams. The tests showed that the control scheme, designed for a multi-variable, non-linear and highly coupled system, tolerates well the operating variables changes, disturbances and parametric variation. The consideration of the compressor map enables to restrain the capabilities of the PEMFC system to prevent mechanical instability and damage, and fuel cell aging; although an additional frequency analysis is necessary to determine the power density capacity of the fuel cell.

The control scheme proposed can facilitate the control implementation on real systems, since the controllers can be commercially available. However, it was necessary to incorporate an adaptive controller in the air temperature loop due to the nonlinear dynamics of the heat exchanger.

The set Aspen Plus ${ }^{\circledR}$-Aspen Exchanger Design and Rating ${ }^{\circledR}$-Aspen Dynamics ${ }^{\circledR}$-Aspen Custom Modeler ${ }^{\circledR}$ is advantageous to simulate the BOP, because it makes possible to obtain more realistic behavior of the auxiliary equipment, and to consider thermal, thermodynamic and fluidic phenomena occurring in the system. The built libraries allow to consider the electrochemical phenomena that characterize the fuel cell operation that are not available in the process simulator.

Acknowledgments: The authors would like to thank SEP-CONACYT for the support of this project under Grant CB-2013/221988 and project 252003 "Programa de Redes Temáticas (RTH2)”. Jose Francisco Gomez Aguilar and Victor M. Alvarado acknowledge the support provided by CONACYT: catedras CONACYT para jovenes investigadores 2014.

Author Contributions: All authors conceived the project design, revised and approved the final manuscript and contributed to the scientific content of the paper. Alan Cruz wrote the programs for aspenONE and Matlab. Guadalupe Lopez and Cinda Sandoval wrote the paper. Guadalupe Lopez performs the analysis and the conclusions. Victor Alvarado corrected the design of the controllers and made the graphs. Victor Alvarado and Francisco Gomez supervised the work.

Conflicts of Interest: The authors declare no conflict of interest.

\section{References}

1. HYUNDAI ix35 Fuel Cell. Available online: http://worldwide.hyundai.com/WW/Showroom/Eco/ix35Fuel-Cell/PIP/index.html (accessed on 7 March 2016).

2. TOYOTA Mirai Fuel Cell Vehicle. Available online: https://ssl.toyota.com/mirai/fcv.html (accessed on 5 January 2017).

3. HONDA Clarity Fuel Cell. Available online: http://automobiles.honda.com/clarity (accessed on 5 January 2017).

4. Mercedes-Benz Crossing the Desert with the B-Class F-CELL. Available online: https://www. mercedes-benz.com/en/mercedes-benz/innovation/crossing-the-desert-with-the-b-class-f-cell/ (accessed on 5 January 2017).

5. Compare Fuel Cell Vehicles. Available online: http://www.fueleconomy.gov/feg/fcv_sbs.shtml (accessed on 7 March 2016).

6. California Fuel Cell Partnership 2016. Available online: http://cafcp.org/ (accessed on 7 March 2016).

7. Pukrushpan, J.T.; Stefanopoulou, A.G.; Peng, H. Control of Fuel Cell Power Systems: Principles, Modeling, Analysis and Feedback Design; Springer Science \& Business Media: Berlin, Germany, 2004.

8. Fang, C.; Li, J.; Xu, L.; Ouyang, M.; Hu, J.; Cheng, S. Model-based fuel pressure regulation algorithm for a hydrogen-injected PEM fuel cell engine. Int. J. Hydrogen Energy 2015, 40, 14942-14951.

9. Hahnel, C.; Aul, V.; Horn, J. Power efficient operation of a PEM fuel cell system using cathode pressure and excess ratio by nonlinear model predictive control. In Proceedings of the 2015 European Control Conference (ECC), Linz, Austria, 15-17 July 2015; pp. 3340-3345.

10. Hahnel, C.; Aul, V.; Horn, J. Error handling approach of a PEM fuel cell system by nonlinear model predictive control. In Proceedings of the 23th Mediterranean Conference on Control and Automation (MED), Torremolinos, Spain, 16-19 June 2015; pp. 508-513.

11. Pilloni, A.; Pisano, A.; Usai, E. Observer-Based Air Excess Ratio Control of a PEM Fuel Cell System via High-Order Sliding Mode. IEEE Trans. Ind. Electron. 2015, 62, 5236-5246.

12. Ou, K.; Wang, Y.X.; Li, Z.Z.; Shen, Y.D.; Xuan, D.J. Feedforward fuzzy-PID control for air flow regulation of PEM fuel cell system. Int. J. Hydrogen Energy 2015, 40, 11686-11695. 
13. Zhang, J.; Liu, G.; Yu, W.; Ouyang, M. Adaptive control of the airflow of a PEM fuel cell system. J. Power Sources 2008, 179, 649-659.

14. Degliuomini, L.N.; Zumoffen, D.; Basualdo, M.; Feroldi, D.; Riera, J. Adaptive predictive robust control for fuel cells hybrid vehicles. In Proceedings of the IEEE Vehicle Power and Propulsion Conference (VPPC), Lille, France, 1-3 September 2010; pp. 1-6.

15. Kavya, V.R.; Padmavathy, K.S.; Shaneeth, M. Steady state analysis and control of PEM fuel cell power plant. In Proceedings of the 2013 International Conference on Control Communication and Computing (ICCC), Thiruvananthapuram, India, 13-15 December 2013; pp. 233-237.

16. Swain, P.; Jena, D. Modeling, simulation \& optimal control of non-linear PEM fuel cell with disturbance input. In Proceedings of the International Conference on Innovations in Information, Embedded and Communication Systems (ICIIECS), Coimbatore, India, 19-20 March 2015; pp. 1-7.

17. Lebreton, C.; Benne, M.; Damour, C.; Yousfi-Steiner, N.; Grondin-Perez, B.; Hissel, D.; Chabriat, J.P. Fault Tolerant Control Strategy applied to PEMFC water management. Int. J. Hydrogen Energy 2015, 40, 10636-10646.

18. De Jesus Rubio, J.; Gomez, J.C.; Cortes, C.A.; Huesca, E.E.; Bravo, A.G. Experimental control of a fuel cell. IEEE Latin Am. Trans. 2015, 13, 2935-2940.

19. Torreglosa, J.; Jurado, F.; García, P.; Fernández, L. PEM fuel cell modeling using system identification methods for urban transportation applications. Int. J. Hydrogen Energy 2011, 36, 7628-7640.

20. Wang, F.; Ouyang, Q.; Chen, J.; Su, H. Feedback linearization control of the air supply system of PEM fuel cells. In Proceedings of the 10th Asian Control Conference (ASCC), Kota Kinabalu, Malaysia, 31 May-3 June 2015; pp. 1-6.

21. Torres, S.O.A.; de Mesquita, A.C.; de Miranda, P.E.V. Control Strategy for Balance of Plant in Solid Oxide Fuel Cell. IEEE Latin Am. Trans. 2013, 11, 726-736.

22. Choudhury, S.D.; Bhardwaj, V.M.; Nandikesan, P.; Mohanty, S.; Shaneeth, M.; Kamalakaran, K.P. Control strategy for PEM fuel cell power plant. In Proceedings of the 1st International Conference on Power and Energy in NERIST (ICPEN), Nirjuli, India, 28-29 December 2012; pp. 1-3.

23. Panos, C.; Kouramas, K.; Georgiadis, M.; Pistikopoulos, E. Modelling and explicit model predictive control for PEM fuel cell systems. Chem. Eng. Sci. 2012, 67, 15-25.

24. Meidanshahi, V.; Karimi, G. Dynamic modeling, optimization and control of power density in a PEM fuel cell. Appl. Energy 2012, 93, 98-105.

25. Brenna, M.; Foiadelli, F.; Longo, M.; Abegaz, T.D. Integration and Optimization of Renewables and Storages for Rural Electrification. Sustainability 2016, 8, 982.

26. Cheng, S.; Xu, L.; Li, J.; Fang, C.; Hu, J.; Ouyang, M. Development of a PEM Fuel Cell City Bus with a Hierarchical Control System. Energies 2016, 9, 417.

27. Ettihir, K.; Boulon, L.; Agbossou, K. Optimization-based energy management strategy for a fuel cell/battery hybrid power system. Appl. Energy 2016, 163, 142-153.

28. Tang, Y.; Yuan, W.; Pan, M.; Wan, Z. Experimental investigation on the dynamic performance of a hybrid PEM fuel cell/battery system for lightweight electric vehicle application. Appl. Energy 2011, 88, 68-76.

29. Feroldi, D.; Rullo, P.; Zumoffen, D. Energy management strategy based on receding horizon for a power hybrid system. Renew. Energy 2015, 75, 550-559.

30. Adi, V.S.K.; Chang, C. Development of flexible designs for PVFC hybrid power systems. Renew. Energy 2015, 74, 176-186.

31. García, P.; Torreglosa, J.P.; Fernández, L.M.; Jurado, F. Control strategies for high-power electric vehicles powered by hydrogen fuel cell, battery and supercapacitor. Expert Syst. Appl. 2013, 40, 4791-4804.

32. Silva, S.B.; Severino, M.M.; de Oliveira, M.A.G. Sizing and Optimization of Hybrid Photovoltaic, Fuel Cell and Battery System. IEEE Latin Am. Trans. 2011, 9, 817-822.

33. Chang, L.Y.; Chang, J.H.; Chao, K.H.; Chung, Y.N. A Low-Cost High-Performance Interleaved Inductor-Coupled Boost Converter for Fuel Cells. Energies 2016, 9, 792.

34. Arango, E.; Ramos-Paja, C.A.; Calvente, J.; Giral, R.; Serna, S. Asymmetrical Interleaved DC/DC Switching Converters for Photovoltaic and Fuel Cell Applications-Part 1: Circuit Generation, Analysis and Design. Energies 2012, 5, 4590-4623.

35. Grötsch, M.; Mangold, M.; Kienle, A. Analysis of the Coupling Behavior of PEM Fuel Cells and DC-DC Converters. Energies 2009, 2, 71-96. 
36. Kim, C.J.; Hong, T.; Kim, J.; Kim, D.; Seo, D.Y. A Process for the Implementation of New Renewable Energy Systems in a Building by Considering Environmental and Economic Effect. Sustainability 2015, 7, 12870-12890.

37. Ziogou, C.; Voutetakis, S.; Papadopoulou, S.; Georgiadis, M.C. Modeling, simulation and experimental validation of a PEM fuel cell system. Comput. Chem. Eng. 2011, 35, 1886-1900.

38. Kabir, M.J.; Chowdhury, A.A.; Rasul, M.G. Pyrolysis of Municipal Green Waste: A Modelling, Simulation and Experimental Analysis. Energies 2015, 8, 7522-7541.

39. Kuo, P.C.; Wu, W. Design, Optimization and Energetic Efficiency of Producing Hydrogen-Rich Gas from Biomass Steam Gasification. Energies 2015, 8, 94-110.

40. Begum, S.; Rasul, M.G.; Akbar, D.; Cork, D. An Experimental and Numerical Investigation of Fluidized Bed Gasification of Solid Waste. Energies 2014, 7, 43-61.

41. Begum, S.; Rasul, M.G.; Akbar, D.; Ramzan, N. Performance Analysis of an Integrated Fixed Bed Gasifier Model for Different Biomass Feedstocks. Energies 2013, 6, 6508-6524.

42. Rabbani, A.; Rokni, M. Dynamic characteristics of an automotive fuel cell system for transitory load changes. Sustain. Energy Technol. Assess. 2013, 1, 34-43.

43. Salemme, L.; Menna, L.; Simeone, M. Calculation of the energy efficiency of fuel processor-PEM (proton exchange membrane) fuel cell systems from fuel elementar composition and heating value. Energy 2013, 57, 368-374.

44. Salemme, L.; Menna, L.; Simeone, M.; Volpicelli, G. Energy efficiency of membrane-based fuel processors-PEM fuel cell systems. Int. J. Hydrogen Energy 2010, 35, 3712-3720.

45. Suther, T.; Fung, A.; Koksal, M.; Zabihian, F. Macro Level Modeling of a Tubular Solid Oxide Fuel Cell. Sustainability 2010, 2, 3549-3560.

46. Pei, P.; Chen, H. Main factors affecting the lifetime of Proton Exchange Membrane fuel cells in vehicle applications: A review. Appl. Energy 2014, 125, 60-75.

47. Ji, M.; Wei, Z. A Review of Water Management in Polymer Electrolyte Membrane Fuel Cells. Energies 2009, 2, 1057-1106.

48. Pukrushpan, J.; Stefanopoulou, A.G.; Peng, H. Modeling and control for PEM fuel cell stack system. In Proceedings of the IEEE American Control Conference, Anchorage, AK, USA, 8-10 May 2002; Volume 4, pp. 3117-3122.

49. Auger, D. Drive Cycles Blockset; Cranfield University: Cranfield, UK, 2013.

50. Azib, T. Contribution à $l^{\prime}$ Etude d'Electro-Générateurs à Pile à Combustible. Conceptions d'Architectures et de Leurs Commandes. Ph.D Thesis, University of Paris-Sud, Orsay, France, 2010.

(C) 2017 by the authors; licensee MDPI, Basel, Switzerland. This article is an open access article distributed under the terms and conditions of the Creative Commons Attribution (CC-BY) license (http:/ / creativecommons.org/licenses/by/4.0/). 